\title{
Some Biogeochemical Characteristics of the Trace Element Bioaccumulation in the Benthic Fauna of the Piip Volcano (The Southwestern Bering Sea)
}

\author{
Liudmila L. Demina * (D), Sergey V. Galkin, Elena M. Krylova, Dmitry F. Budko and Aleksandra S. Solomatina \\ Shirshov Institute of Oceanology RAS, 36 Nakhimovsky Prospect, 117997 Moscow, Russia; \\ galkin@ocean.ru (S.V.G.); elenamkr@mail.ru (E.M.K.); dmitry.b-1990@yandex.ru (D.F.B.); \\ blackmaple@yandex.ru (A.S.S.) \\ * Correspondence: 1_demina@mail.ru; Tel.: +79-63-608-1747
}

Citation: Demina, L.L.; Galkin, S.V.; Krylova, E.M.; Budko, D.F.; Solomatina, A.S. Some

Biogeochemical Characteristics of the Trace Element Bioaccumulation in the Benthic Fauna of the Piip Volcano (The Southwestern Bering Sea). Minerals 2021, 11, 1233. https:// doi.org/10.3390/min11111233

Academic Editors: Marcella Di Bella, Francesco Italiano, Valentina Esposito and Annalisa Ferretti

Received: 24 September 2021 Accepted: 1 November 2021 Published: 6 November 2021

Publisher's Note: MDPI stays neutral with regard to jurisdictional claims in published maps and institutional affiliations.

Copyright: (c) 2021 by the authors. Licensee MDPI, Basel, Switzerland. This article is an open access article distributed under the terms and conditions of the Creative Commons Attribution (CC BY) license (https:// creativecommons.org/licenses/by/ $4.0 /)$.
Abstract: The Piip Volcano is a submarine volcanic edifice occupying the central part of the Volcanologists Massif in the southwestern Bering Sea, with two tops, southern and northern. The minimum depth of the northern top is located at $368 \mathrm{~m}$, and of the southern at $464 \mathrm{~m}$. Active hydrothermal venting occurring at both summits of the volcano supports diverse biological communities, including animals specific for chemosynthetic habitats. In benthic organisms inhabiting the northern and southern tops of the Piip Volcano, for the first time, we examined distribution patterns of the following trace elements: titanium, vanadium, chromium, manganese, iron, nickel, copper, zinc, arsenic, selenium, zirconium, molybdenum, silver, cadmium, antimony, barium, tungsten, lead, bismuth, and uranium. The element contents were quantified by the ICP-MS. Total carbon (TC) and total inorganic carbon (TIC) were determined using a Shimadzu TOC-L-CPN and mineral composition of sediment was determined using the XRD. In the water of the biotope from the northern top, concentrations of $\mathrm{Mn}, \mathrm{Zn}, \mathrm{Ag}, \mathrm{Cd}, \mathrm{Sb}, \mathrm{W}, \mathrm{Pb}$ were 2-6 times, and Ba was 50 times higher than those from the southern top. This was attributed to the lower temperature of fluids emanating at the southern top. An abundant population of Calyptogena pacifica (Bivalvia: Vesicomyidae: Pliocardiinae) was found only at the southern top. The main target of most trace elements, such as $\mathrm{Fe}, \mathrm{V}, \mathrm{Cr}, \mathrm{Co}, \mathrm{Ni}, \mathrm{Zn}, \mathrm{As}, \mathrm{Mo}, \mathrm{Ag}$, $\mathrm{Cd}, \mathrm{W}, \mathrm{Pb}, \mathrm{Bi}$, and $\mathrm{U}$ were the soft parts of Calyptogena pacifica (with high TOC content, on average $53.1 \%$ in gills and $49.6 \%$ in the rest of the body). Gills were characterized by particular high contents ( $>100 \mu \mathrm{g} \mathrm{g}^{-1}$ dry w.) of $\mathrm{Zn}, \mathrm{Cd}, \mathrm{Fe}, \mathrm{Ni}, \mathrm{Cu}$, and $\mathrm{Pb}$, which can form sulphides or be associated with them. Shells of C. pacifica, as well as Brachiopoda, were depleted in these elements, as well as tissues of the carnivores Paguridae (Crustacea) and Actiniaria (Anthozoa). In suspension feeders from both tops, the lower contents of most elements were detected. Estimation of Biological Concentration Factor (BCF) for most elements varied from $10^{2}$ to $10^{4}$, reaching $\mathrm{n} 10^{5}$ for $\mathrm{Ni}, \mathrm{Zn}, \mathrm{Ag}, \mathrm{Cd}$, and $\mathrm{Pb} . \mathrm{A}$ significant difference in BCF values between Fe and Mn was revealed.

Keywords: trace element; toxic conditions; hydrothermal vents; Volcanologists Massif; TOC; gills; Calyptogena pacifica; suspension-feeders; carnivores

\section{Introduction}

Hydrothermal venting is known to be a source of many trace elements in the ocean [1-6]. Recently, a strong impact of hydrothermal fluids on biogeochemical cycles of metals in the ocean has become apparent thanks to numerous large-scale studies in the framework of the international GEOTRACERS program (www.geotraces.org, 3 September 2021). The role of Fe and other metals' complexation with dissolved organic matter and interaction with nanoparticles for metal export into the ocean was found to be of importance [7-12]. In terms of biogeochemistry, deep-sea hydrothermal fields are of particular interest, since processes of both dispersion and concentration of trace elements, supplied by the hydrothermal fluids, coexist there. In these areas, the trace elements are concentrated due to mineral 
formation (sulphides or oxyhydroxides) [2], as well as a result of the concentration function of the benthic fauna. At hydrothermal vent fields, the most abundant constituents of communities involve those organisms, whose feeding strategy relies on bacterial symbiotrophy. Symbiotrophic animals functionally depend on reduced compounds of the fluids $\left(\mathrm{H}_{2} \mathrm{~S}, \mathrm{H}_{2}\right.$, and $\mathrm{CH}_{4}$ ) serving as an energy source for bacterial chemosynthesis [13-16]. The deep-sea hydrothermal biological communities demonstrate a great concentration function that is reflected in the high values of the bioconcentration factor (BCF). In the case of Bathymodiolus mussels, collected from the four Mid-Atlantic Ridge (MAR) hydrothermal fields, BCF values varied from $\mathrm{n} 10^{2}$ to $10^{5}$ [17-21]. Among heavy metals, $\mathrm{Fe}, \mathrm{Mn}$, and $\mathrm{Zn}$ showed the highest content, both in the organisms' tissues (up to $105 \mu \mathrm{g} \mathrm{g}^{-1}$ dry w.) and also in fluids [21-26]. The levels of heavy metals in the hydrothermal areas and the areas subject to anthropogenic loads are close in order of magnitude [18]. The deep-sea hydrothermal biological communities demonstrate a great concentration function that is reflected in the high values of the bioconcentration factor (BCF). In the case of Bathymodiolus mussels collected from the four Mid-Atlantic Ridge (MAR) hydrothermal fields, the BCF values varies from $\mathrm{n} 10^{2}$ to $\mathrm{n} 10^{5}$ [17-21]. Among heavy metals, $\mathrm{Fe}, \mathrm{Mn}$, and $\mathrm{Zn}$ showed the highest content both in the organisms' tissues (up to $10^{5} \mu \mathrm{g} \mathrm{g}^{-1}$ dry w.) and also in fluids [21-26]. The levels of heavy metals in the hydrothermal areas and in the areas subject to anthropogenic loads are close in order of magnitude [18].

The first data on the benthic communities at areas of hydrothermal manifestations of the Piip Volcano was obtained during the 22nd cruise of RV "Akademik Mstislav Keldysh" in 1990 using the human-occupied vehicle (HOV) "Mir" [27]. It was observed that on the northern and southern summits of the volcano, in addition to several active anhydrite and carbonate hydrothermal structures with focused methane emanations, there were large areas of diffuse emissions. On the northern top with a minimum depth of $368 \mathrm{~m}$, seeps were located under rocky scree and boulders of dacite lavas, whereas on the southern one, with a minimum depth of $464 \mathrm{~m}$, seeps were mostly placed in the sub-meridional positioned tectonic fractures of carbonate crusts. As a result of the first studies, two main features of the hydrothermal communities were noted. The first feature was the presence of the intensively developed bacterial mats marking the methane seeping. Particularly abundant mats were observed on the northern summit, where their coverage reached $100 \%$ on areas up to $100 \mathrm{~m}^{2}$ [27]. The second feature was the presence of symbiotrophic bivalve molluscs of the genus Calyptogena (Vesicomyidae, Pliocardiinae), obligate for reducing environments. Calyptogena clams were found exclusively on the southern summit. Subsequently, this species was identified as Calyptogena pacifica Dall, 1891 [28]. The Piip Volcano is one of the shallowest habitats, where specialized pliocardiines were registered.

In 2016, during the 75th cruise of RV "Akademik M.A. Lavrentyev" investigations of the benthic fauna on the northern and southern tops of the Piip Volcano were continued using the remotely operated vehicle (ROV) "Comanche- 18 ". On the northern top, most extensive bacterial mats were found above a depth of $450 \mathrm{~m}$. However, single mats were observed also at $600 \mathrm{~m}$ depths, and the deepest bacterial mat was located in $55.445^{\circ} \mathrm{N}$, $167.263^{\circ} \mathrm{E}$, at a depth of $1835 \mathrm{~m}$. As a result of investigations conducted during the 75th cruise, the presence of Calyptogena on the southern top was confirmed, as well as some single shells were also found on the northern top. Besides of bivalves, lysianassid amphipods were registered on both the summits exclusively in bacterial mats, where their density reached 50 ind. $/ \mathrm{dm}^{2}$. Two dives were carried out on the northern and southern tops in order to assess the nature and extent of the impact of hydrothermal manifestations on the composition and distribution of bottom fauna, and to identify the role of bacterial production in the nutrition of dominant animals in different distances from hydrothermal vents $[29,30]$.

Along with the comprehensive investigations mentioned above, our knowledge of the biogeochemistry of the benthic community inhabiting the Piip Volcano is still fragmented. An overall estimation of chemical element distribution in different components of this ecosystem influenced by the low-temperature hydrothermal diffuse fluids is absent. We 
hypothesized that the benthic organisms inhabiting the Piip Volcano accumulate trace elements from the environment at different extents, depending mostly on their feeding type and the element content in the environment. The hydrothermal vent community of the Piip Volcano is still poor studied, particularly because of the difficulties of sampling in the deep-sea hydrothermal environment. In this study, for the first time we seek to clarify the distribution pattern of chemical elements in the benthic fauna and sediments of the Piip Volcano. To achieve it, we (1) determined elemental composition, including heavy metals (both essential and potentially toxic), of benthic organisms, their substrate and ambient seawater; (2) estimated environmental and geochemical factors that influence on the trace element distribution in the different animals; (3) revealed peculiarities of trace metal bioaccumulation in the organisms of different trophic level and nutrition type. The data obtained might contribute to the deeper knowledge of the metal bioaccumulation by bottom organisms and detoxification mechanisms they may use, as well as understanding the environmental factors that influence this process.

\section{Materials and Methods}

\subsection{Study Area}

In the last 25 years, investigations into the geological characteristics of the submarine Piip Volcano were carried out in expeditions of the Institute of Volcanology of the FarEastern Branch of RAS and Shirshov Institute of Oceanology of RAS. In these cruises, the deep-sea manned submersibles "MIR" were used for targeted sampling of geological and biological materials, new hydrothermal ore-bearing deposits were discovered [31-33].

The Piip Volcano, an active volcano in the southwestern Bering Sea, was discovered in 1984 [33]. The Piip Volcano is located in the southern Komandor Deep in the rear of the Aleutian Islands arc and constitutes a central part of the Volcanologist's Massive. The latter lays in the depths' interval of 3000-349 m within the large graben that arose due to back-arc spreading [34]. The features of the modern hydrothermal activity were detected by the abnormally high values of heat flow. In seawater, an acoustic anomaly caused by the gas bubbles, as well as the low Eh values and high concentrations of $\mathrm{CH}_{4}, \mathrm{H}_{2} \mathrm{~S}, \mathrm{Mn}^{2+}$. In bottom sediments, the ash layers were found to date back to around 7000 years ago (time of the last eruption [34].

The Piip Volcano is composed of three fused edifices, northern, central, and southern, among which the northern and southern ones are higher; these tops resemble a submeridional chain. The northern top with a minimum depth of $\sim 360 \mathrm{~m}$ was formed by andesite and dacite. There, hydrothermal manifestation happens at depths of less than $650 \mathrm{~m}$, where shimmering water and bacterial mats were observed. A local discharge of hydrothermal fluids occurred through the anhydrite edifices (up to $1.5 \mathrm{~m}$ high) emitting milky-white fluid from the top. The seafloor around these edifices was covered with white-coloured hydrothermal deposits composed of crystallized gypsum with an admixture of anhydrite. At a distance from the vent edifices, the seafloor is covered with the nonconsolidated ochre-coloured deposits composed of opal and pyrite. On the southern top, located deeper than $460 \mathrm{~m}$ and $3.86 \mathrm{~km}$ southwards the northern one, the second type of hydrothermal manifestation was revealed [34]. The southern top and slopes are composed of dacite pumice, while in its centre, a large hydrothermal structure, shaped like a long hill to $10 \mathrm{~m}$ height, is presented by mostly barite and Ca carbonate. On the southern top, the local vents are associated with small (up to $40 \mathrm{~cm}$ ) conical carbonate structures [27].

At the Piip Volcano's tops, both the reduced and the oxidized facies of hydrothermal sediments were revealed. The reduced facies were represented by anhydrite, gypsum, barite, and carbonate (aragonite) with sulfidic (pyrite) particles; the latter were dispersed in opal, anhydrite, barite, calcite, and aragonite. The anhydrite deposits are formed at a rather wide range of temperature, 180 to $360^{\circ} \mathrm{C}$, while a hydrothermal solution is mixed with bottom ocean water which contains sulphate-ion $\mathrm{SO}_{4}{ }^{2-}$ [35]. A more accurate temperature interval for anhydrite precipitation was estimated as $250-360^{\circ} \mathrm{C}$ [33]. Taking into account a phase separation of the initial hydrothermal solution during circulation, the non-ore 
minerals were assumed to be deposited within the middle-temperature conditions [36]. According to the micro-SEM-X-ray analysis, in pyrites, the abnormally high contents of As, $\mathrm{Sb}, \mathrm{Hg}$, and $\mathrm{Ag}(0.10 \%$ to $4.10 \%)$ were detected [32]. Such high contents of these elements in pyrites were not observed in the other hydrothermal deposits in the ocean rift zones [36]. The oxidized facies, that were widely developed at the periphery of the active hydrothermal field, were composed of the poorly crystallized orange-yellow oxyhydroxides of $\mathrm{Fe}$, and black Mn minerals (rhombic birnessite) depleted in trace elements, these minerals were characteristic for most of the low-temperature hydrothermal deposits [31].

\subsection{Materials}

For this study, the field material was sampled on the underwater active Piip Volcano $\left(55^{\circ} 25^{\prime} \mathrm{N}, 167^{\circ} 20^{\prime} \mathrm{E}\right)$ during the 82nd cruise of RV Akademik M.A. Lavrentyev, conducted by the A.V. Zhirmunsky National Scientific Centre of Marine Biology (June-July 2018) (Figure 1).

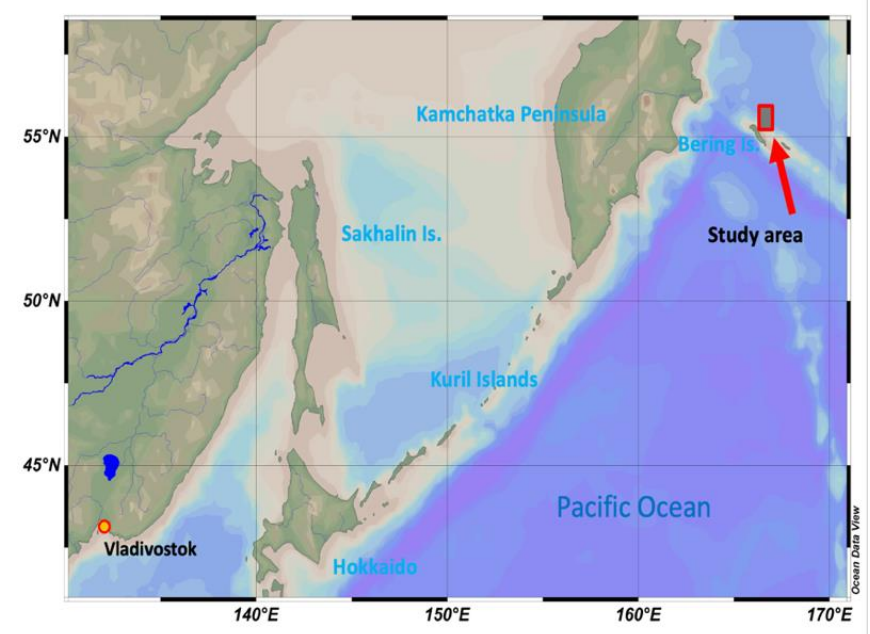

(a)

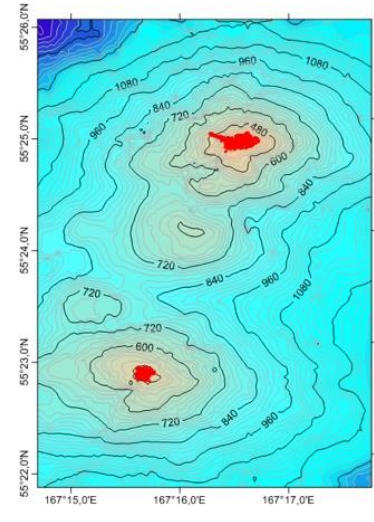

(b)

Figure 1. Location of the submarine Piip Volcano in the in the rear of the Aleutian Islands' arc, the south-eastern Bering Sea (a), and bathymetry of its northern and southern tops (b). The red patches indicate areas covered with bacterial mats marking the diffuse seepage.

The area of hydrothermal manifestations of the Piip Volcano was investigated during 4 dives of the ROV Comanche-18 [30]. Along with a few active hydrothermal structures, the large areas of diffuse seepage were recorded (Figure 2).

At the northern top, these outflows are located under fragmented dacitic lavas, while on the southern top, they are mostly associated with cracks in the carbonate deposits [30]. These two sites differ in such basic environmental parameters as the temperature of hydrothermal fluids, as well as bottom deposits which serve as a substratum for fauna. The northern top is composed of the anhydrite deposits, temperature (measured for first time) of "the white smoker's" fluids was equal to $132.79^{\circ} \mathrm{C}$, and the methane concentration in bottom water reached $2364 \mathrm{nl} \mathrm{l}^{-1}$ (90.5\% of total gas content). The southern top, where the temperature was $10.59^{\circ} \mathrm{C}$ and the concentration of $\mathrm{CH}_{4}$ was $2970 \mathrm{nl} \mathrm{l}-1$ (92\% of total gas content), is composed of carbonate material [30,37]. At the southern summit, the bacterial mats are widespread, starting at a depth of $555 \mathrm{~m}$; the reduced conditions appear to predominate in the bottom organisms' environment at the Piip Volcano tops. At the same time, in sediments from the southern top, numerous ice-rafted debris was found.

For this study, 23 specimens of macrofauna, three samples of bottom deposits, two samples of water of the biotope (Table 1) have been collected using the ROV "Comanche18 ". A sampling of fauna and surface sediments was carried out by a manipulator of the ROV. The specimens were placed into a plastic storage container. Fragile or soft organisms of small sizes were sucked into a separate plastic container by a slurp-gun of the ROV. 
To obtain data on the composition of the population of different ecological zones within hydrothermal areas, nets with a stainless-steel frame, equipped with a double bag, were used: the outer bag (knotless nylon mesh with a cell of $4 \mathrm{~mm}$ ), and the inner one (mill sieve with a cell of $250 \mu \mathrm{m}$ ). Onboard the ship, the content of the sack was washed on a strainer with a cell of $500 \mu \mathrm{m}$. In addition, one sample of the bacterial mat was obtained from the substratum of Calyptogena bed at the southern slope. The seawater samples were collected by the plastic Niskin bathometer over the settlement of C. pacifica (Table 1), where the temperature varied from 3.54 to $3.71{ }^{\circ} \mathrm{C}$. The Niskin bathometers were previously purified with diluted nitric acid. Water sampling was carried out under visual control provided by the TV system of ROV Comanche 18, with precautions that minimized the risk of contamination.

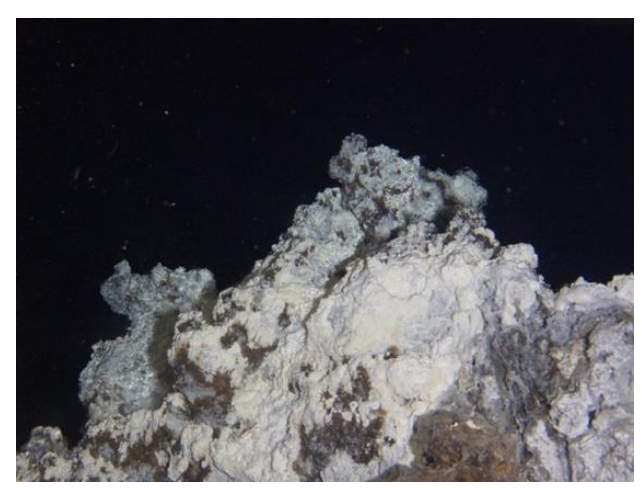

(a)

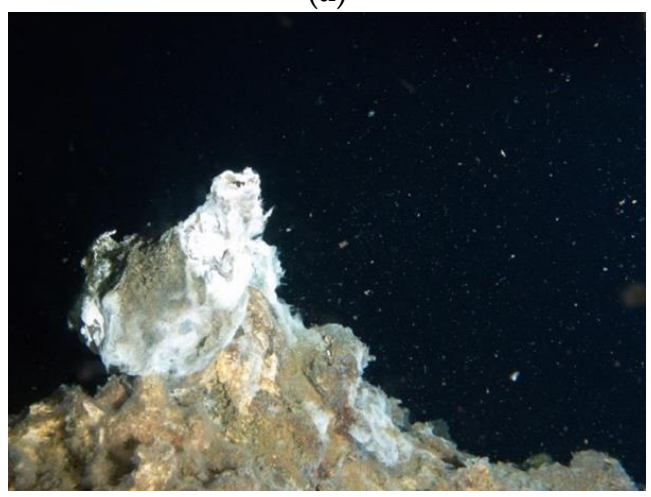

(c)

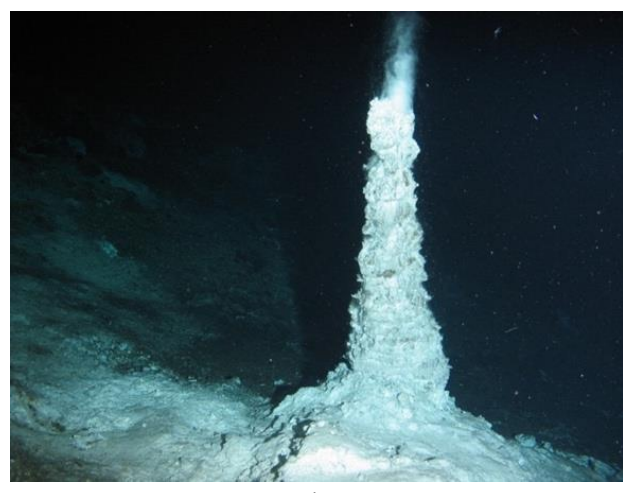

(b)

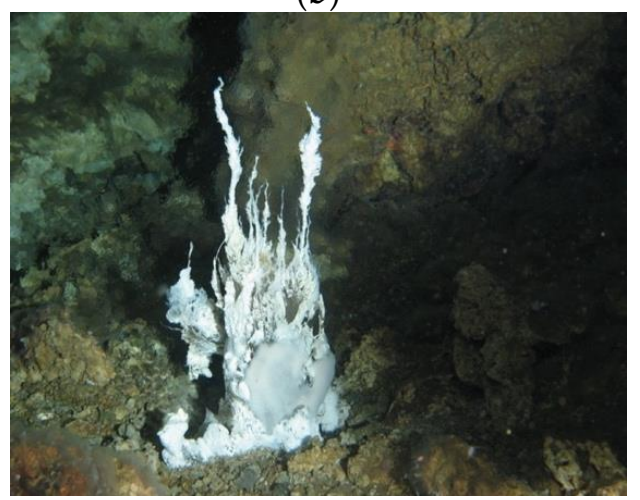

(d)

Figure 2. Hydrothermal vent edifices of the northern $(\mathbf{a}, \mathbf{b})$ and southern $(\mathbf{c}, \mathbf{d})$ tops of the Piip Volcano.

Table 1. The biotope water samples from the Piip Volcano.

\begin{tabular}{ccccccc}
\hline Sample ID & Station & Location & Latitude N & Longitude E & $\begin{array}{c}\text { Sampling } \\
\text { Depth, } \mathbf{m}\end{array}$ & Note \\
\hline L-1 & LV82-2 & $\begin{array}{c}\text { Northern slope } \\
\text { of the volcano }\end{array}$ & $55^{\circ} 24,993$ & $166^{\circ} 16,584$ & 388 & $\begin{array}{c}20 \text { cm from the vent of the active } \\
\text { anhydrite chimney }\end{array}$ \\
\hline L-2 & LV82-4 & $\begin{array}{c}\text { Southern slope } \\
\text { of the volcano }\end{array}$ & $55^{\circ} 22,924$ & $167^{\circ} 15,665$ & 470 & $\begin{array}{c}30 \text { cm from the vent of the active } \\
\text { carbonate chimney (moire) }\end{array}$ \\
\hline
\end{tabular}

Immediately after rising of the ROV with bathometers, the samples of the biotope water were put into the HDPE vials (which were previously washed with purified HNO3), followed by acidification with $\mathrm{HNO} 3$ to $\mathrm{pH} 2$. Concentrated nitric acid used in this study was previously processed by the use of the Sub-boiling system Berghof BSB-939-IR (Germany). Samples were stored in a refrigerator before analysis. 


\subsection{Treatment of Samples, Chemical Analysis, and the Data Statistical Processing}

Onboard the ship, water samples were transferred into the acid-washed flasks, followed by adding the nitric acid $(69 \% v / v)$ to $\mathrm{pH} 2$. Water samples were stored in a refrigerator until the analysis in the stationary laboratory. The animals' specimens were washed with seawater. Then, the individuals were rinsed with distilled water using a toothbrush, followed by preparation of the clams into shells, gills, and body tissues. Among the suspension-feeders, specimens of Brachiopoda were separated into body and shell, while the rest of taxa, as Echinodermata and Crustacea, were taken as the whole bodies. Onboard the ship, specimens of organisms and sediments were dried in a thermostat at $55^{\circ} \mathrm{C}$. The dried samples were stored in insulated plastic bags for analysis.

In the stationary laboratory, before the ICP-MS analysis, to minimize the matrix effect, the water samples were diluted $(1: 4 \mathrm{v} / \mathrm{v})$ with $5 \% \mathrm{HNO}_{3}$. To monitor and account for drift of the device's sensitivity, as well as matrix effects in samples and calibration solutions, the internal indium standard solution was added, so that its amount in all measured samples was $10 \mathrm{ppb}$. The dried samples of bottom fauna and sediments before the analysis were powdered in the agate mortar. The complete digestion of samples (mass did not exceed $60 \mathrm{mg}$ ) was performed in a mixture of $2 \mathrm{~mL}$ concentrated nitric acid (HNO3, 69\% v/v, super-pure MERCK) and $1 \mathrm{~mL}$ of hydrogen peroxide ( $\mathrm{H} 2 \mathrm{O} 2,30 \%)$ in Teflon vessels on a heating platform at $80-90{ }^{\circ} \mathrm{C}$. In the case of sediments, $3 \mathrm{~mL}$ of concentrated hydrofluoric acid (HF, 36\% v/v) was also added in Teflon vessels of MWS-2 microwave system Speed Wave (Berghof, Products+Instruments, GmbH, Mühlhausen, Germany). After evaporating to the moist salts, the final volume $(30 \mathrm{~mL})$ was set in the HDPE vial with $5 \%$ solution of HNO3. For every 7 specimens, one blank analysis was performed. The concentrations of the chemical elements (Ti, V, Cr, Mn, Fe, Ni, Cu, Zn, As, Se, Zr, Mo, Ag, Cd, Sb, W, Pb, Bi, and $\mathrm{U}$ ) in samples were determined using the X-7 Thermo Elemental ICP-MS instrument (Santa Clara, CA, USA) with a precision varied between $0.3 \%$ and $7.8 \%$ determined from 2 replicas out of 5 samples. The detection limits of the examined elements are listed in Table 2.

Table 2. Detection limits for the elements in the bottom organisms, sediments, and water of the biotope.

\begin{tabular}{ccccccccccccc}
\hline & $\mathbf{A l}$ & $\mathbf{T i}$ & $\mathbf{V}$ & $\mathbf{C r}$ & $\mathbf{M n}$ & $\mathbf{F e}$ & $\mathbf{C o}$ & $\mathbf{N i}$ & $\mathbf{C u}$ & $\mathbf{Z n}$ & $\mathbf{A s}$ \\
\hline Sediments and Organisms, ppm & 41.44 & 2.2 & 0.32 & 2.03 & 1.58 & 351 & 0.12 & 1.96 & 2.65 & 5.28 & 0.67 \\
\hline Water, ppb & $\mathrm{nd}$ & 0.3 & 0.02 & 0.28 & 0.33 & 53 & 0.03 & 0.27 & 0.25 & 2.12 & 0.04 \\
\hline Sediments and Organisms, ppm & 1.30 & 2.1 & 0.65 & 0.31 & 0.13 & 1.4 & 0.11 & 1.49 & 0.12 & 4.60 & 0.03 \\
\hline Water, ppb & 1.79 & 0.3 & 0.56 & 0.07 & 0.02 & 0 & 0.03 & 0.35 & 0.05 & 0.53 & nd \\
\hline
\end{tabular}

nd $=$ not detected.

The analysis of accuracy was controlled with the Certified Reference Material of the National Institute of Standards of Canada SRM NIST SRM 2976 (mussel tissues), and NIST 2702 (marine bottom sediments), and SLEW NRC-CNRC (estuarine water) with yielding deviation $0.7 \%$ to $9.5 \%$ for different elements. Contents of total carbon (TC) and total inorganic carbon (TIC) were determined by the automatic coulometry on a Shimadzu TOC-L-CPN analyser (Tokyo, Japan). The essence of the method is the oxidation of the carbon compounds contained in the sample at a temperature of $900{ }^{\circ} \mathrm{C}$ in the presence of oxygen-containing gas to $\mathrm{CO}_{2}$ followed by subsequent determination of the released $\mathrm{CO}_{2}$ using an infrared detector. The area of the recorded peak is proportional to the organic carbon content in the sample. For bottom sediments, the range of reliably measured carbon concentrations was $25-10,000 \mu \mathrm{g} C$ with the sample mass of 25 to $100 \mu \mathrm{g}$. The detection limit of TOC and TIC determination was $0.01 \mathrm{wt} . \%$, the mean standard error was $1 \%$, reproducibility of test results $\pm 5 \%$. Before the start of the series of analyses, the instrument was calibrated according to standard solutions of potassium hydro-phthalate and the SDO-2 (volcano-terrigenous sediment) and SDO-3 (carbonate sediment) Certified 
Sediment Reference Material. The Total Organic Carbon (TOC) contents were calculated as a difference between TC and TIC Mineralogical analysis of sediments was carried by the XRD diffractometry with a D8 ADVANCE (Bruker AXC, Karlsruhe, Germany).

Statistical data processing was performed by the use of the software package Statistica 10 (TIBCO Software Inc., Palo Alto, CA, USA). Correlations between element concentrations in the organism examined were calculated using Spearman's rank correlation coefficients (Spearman correlation; a non-parametric measure of the strength of two variables' relationship with no distribution assumptions and minimal sensitivity to outliers; significant if $\rho s \geq 0.2$ and $p<0.05$ ). Ward's hierarchical cluster analysis (HCA) was applied to group selected organisms and their tissues by the common features of elemental composition [38].

\section{Results}

\subsection{Element Composition of the Selected Organisms}

In this work, the bottom organisms were divided into three groups along with their trophic level or nutrition character. Group 1 was presented by the specialized symbiotrophic pliocardiine clam Calyptogena pacifica that was observed exclusively on the southern summit of the Piip's Volcano. Group 2 includes the seston- and plankton-feeders: Brachiopoda; Anthozoa (subclass Hexacorallia: Zoantharia, Actiniaria, and Corallimorpharia); (subclass Octocorallia: Alcyoniidae Heteropolypus ritteri), Spongia: Demospongia. Group 3 includes carnivores: 1. Echinodermata: Asteroidea; Crustacea: Paguridae and Chionoecetes opilio. The average concentrations of the elements ( $\mu \mathrm{gg}-1$ dry weight) in the examined specimens of benthic organisms are listed in Table S1.

\subsubsection{Distribution of Trace Elements in the Organisms of Group 1}

Group 1 is represented by the specialized symbiotrophic Calyptogena pacifica. We have examined element distribution in three body parts: gills, the rest of the soft body, and carbonate shell (Figure 3). The length of C. pacifica shells varied from 29.2 to $44.9 \mathrm{~mm}$, $35.3 \mathrm{~mm}$ on average.

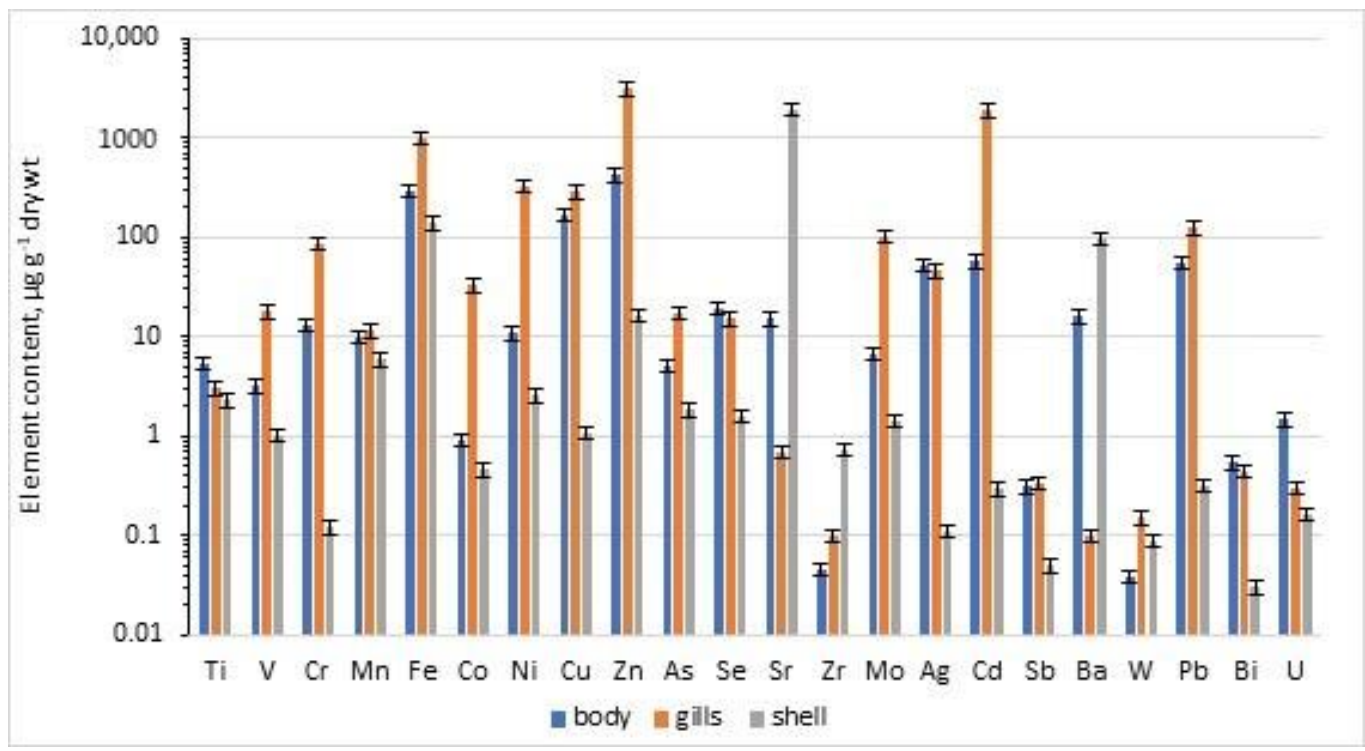

Figure 3. Partitioning of the average element concentrations in the body parts of C. pacifica inhabiting the southern summit of the Piip Volcano.

The endosymbionts hosting gills are characterized by a particularly high content (100 $\mathrm{gg} \mathrm{g}^{-1}$ dry w. and much more) of $\mathrm{Zn}, \mathrm{Cd}, \mathrm{Fe}, \mathrm{Ni}, \mathrm{Cu}, \mathrm{Mo}$, and $\mathrm{Pb}$, which can form sulphides or be associated with them. It should be noticed that an abnormally high average Cd content in gills is similar to that of Fe and Zn levels (around $1000 \mu \mathrm{g} / \mathrm{g}$ dry w.) (Figure 3). Quite a high content (10 to $100 \mu \mathrm{g} \mathrm{g}^{-1}$ dry w.) was also detected for $\mathrm{Cr}, \mathrm{Co}$, Se, 
As, Se, and Ag, while the rest of the elements exhibited the lowered concentrations $(<10$ to $0.02 \mu \mathrm{g} \mathrm{g}^{-1}$ dry w.). The lowest concentration levels in gills $\left(<0.1 \mu \mathrm{g} \mathrm{g}^{-1}\right)$ were detected for $\mathrm{Zr}$ and Ba. Uranium, the concentration of which did not exceed $1 \mu \mathrm{g} \mathrm{g}^{-1}$, revealed a noticeably increased content in the soft body compared to gills and shells, unlike the other elements (Figure 3).

Titanium, Mn, Se, Ag, Sb, and Bi showed no significant difference between their content in gills compared to the rest of the soft body. The clam's shell is a body part with the minimum content of most elements except $\mathrm{Sr}, \mathrm{Zr}$, and Ba. The latter elements exhibited a strongly increased accumulation ( 1 to 2 orders of magnitude) in the shell compared to the other clam's body parts. The calcite shell contains on average $10.7 \%$ TIC, which is almost totally ( $90 \%$ ) composed of $\mathrm{CaCO} 3$ (based on 8.33 coefficient of TIC to $\mathrm{CaCO} 3$ calculation).

The high content of total organic carbon (TOC) was found in the C. pacifica gills and the rest of the soft body ( $53.1 \%$ and $49.6 \%$, respectively) (Table S1).

A sample of the bacterial mat, collected at the southern summit of the Piip Volcano, contained a noticeable amount of phytodetritus, where the alive Protozoa, testae amoebae (Testacea), and foraminiferans were found. So, our sample of the bacterial mat is composed of organic and biomineral substances. The distribution of elements in the bacterial mat in comparison to the C. pacifica gills is displayed in Figure 4.

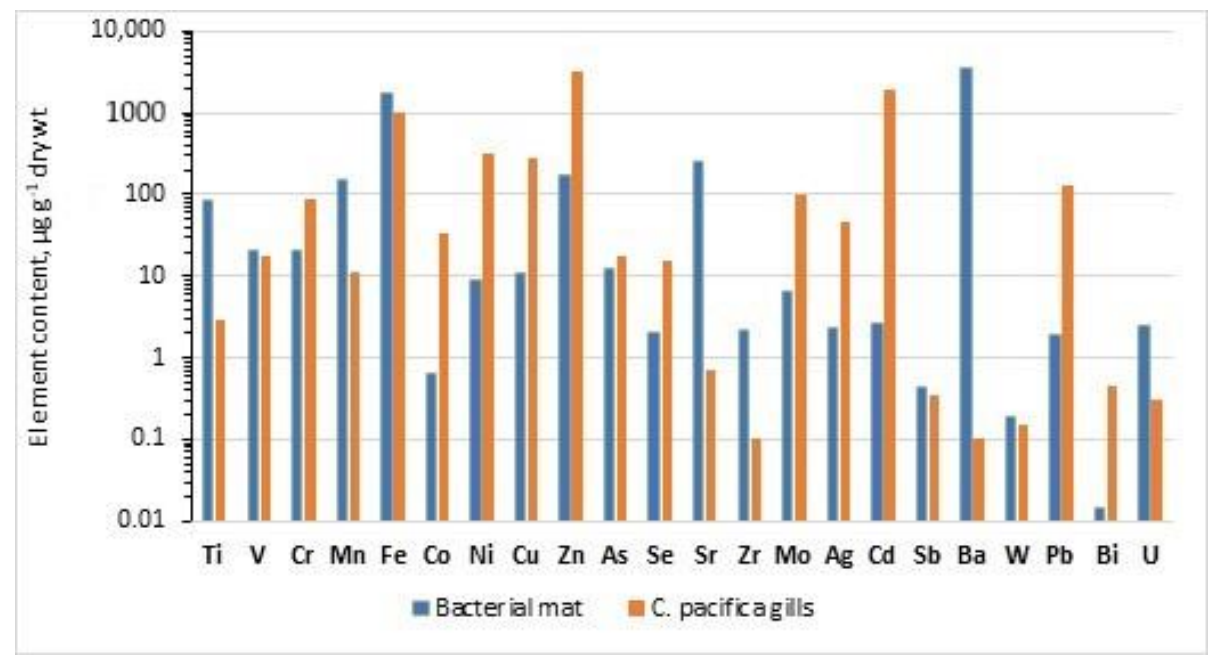

Figure 4. Comparison of the element distribution in bacterial mat and C. pacifica gills.

The bacterial mat, composed not only of alive microorganisms but of biogenic and abiogenic material, concentrations of such lithogenous and constitutional elements as Ti, $\mathrm{Mn}, \mathrm{Sr}, \mathrm{Zr}, \mathrm{U}$, and $\mathrm{Ba}$ are 2 to 4 (for $\mathrm{Ba}$ ) orders of magnitude higher than those in gills. The latter is strongly enriched in $\mathrm{Cr}, \mathrm{Co}, \mathrm{Ni}, \mathrm{Cu}, \mathrm{Zn}, \mathrm{Se}, \mathrm{Mo}, \mathrm{Ag}, \mathrm{Cd}, \mathrm{Pb}$, and $\mathrm{Bi}$ (up to three orders of magnitude, in the case of $\mathrm{Cd}$ ) relative to the bacterial mat. Most of these elements belong to a group of chalcophilic ones. For the rest of the elements $(\mathrm{V}, \mathrm{Fe}, \mathrm{Sb}$, and $\mathrm{W})$, a little difference was observed. It should be noted a very high concentration of $\mathrm{Ba}$ in bacterial mats $\left(4000 \mu \mathrm{g} \mathrm{g}^{-1}\right)$ in comparison to gills and soft bodies $\left(0.1\right.$ and $11 \mu \mathrm{g} \mathrm{g}^{-1}$, respectively). Such a high content of Ba confirms data on Ba accumulation by bacterial biofilms composed of the extracellular polymeric substances (EPS) produced by a large range of microorganisms including phytoplankton and bacteria, that led to barite formation via nucleation in EPS [39].

\subsubsection{Distribution of Trace Elements in the Organisms of Group 2}

Group 2 includes the plankton and seston feeders presented by the three taxa: (1) Brachiopoda; (2) Anthozoa, that included subclass Hexacorallia (Zoantharia, Actiniaria, and Corallimorpharia), and subclass Octocorallia (Alcyonacea: Heteropolypus ritteri); (3) Spongia: Demospongia. The elemental concentrations of these taxa are listed in Table S1. 
In Brachiopoda, collected at the southern summit of the Piip Volcano, we examined the trace elements' partitioning between the soft body tissues and shells (Figure 5).

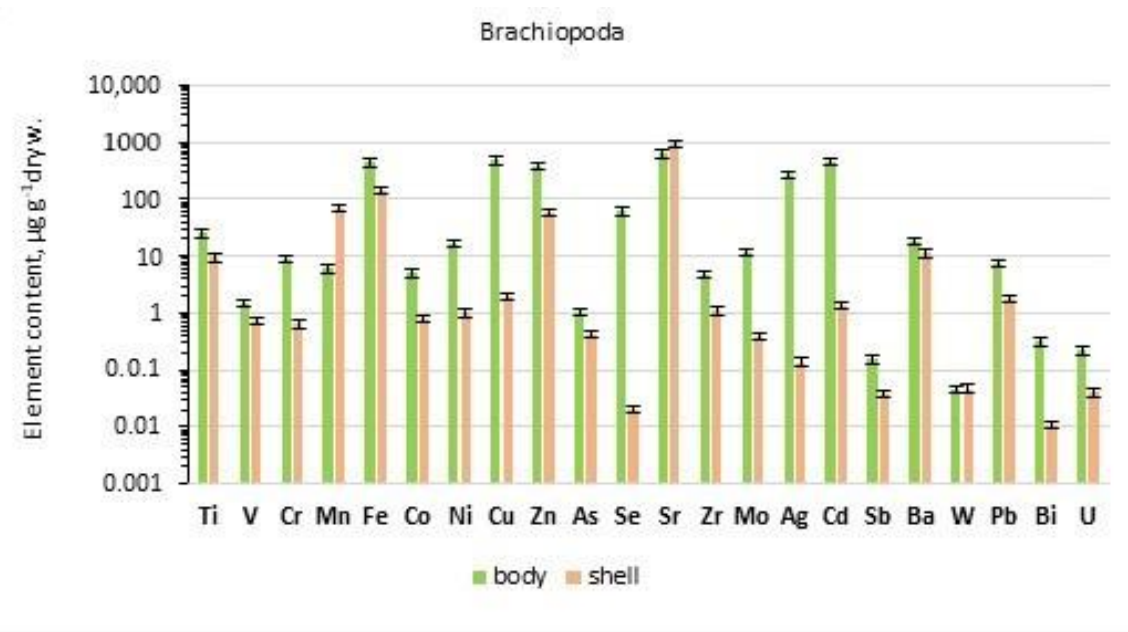

Figure 5. Distribution of the average element concentrations in the Brachiopoda body soft tissues and shell.

In the Brachiopoda soft body tissues, almost all the elements displayed significantly increased concentrations relative to those for the shell. The latter contains $11.12 \%$ TIC, which implies a predominance $(\sim 92 \%)$ of $\mathrm{CaCO} 3$ in the shell's composition. For the soft bodies of Brachiopoda, similarly to those for $C$. pacifica, a particularly big difference between the soft body and shell was observed for chalcophile elements (Fe, $\mathrm{Co}, \mathrm{Ni}, \mathrm{Cu}, \mathrm{Zn}, \mathrm{Se}, \mathrm{Ag}$, $\mathrm{Cd}$, and $\mathrm{Bi}$ ) (Figure 5). It is of interest, that the average $\mathrm{Cd}$ content in Brachiopoda soft body $\left(>100 \mu \mathrm{g} \mathrm{g}^{-1}\right.$ dry w.) is of the same level for $\mathrm{Zn}, \mathrm{Cu}$, and Fe. Unlike the other elements, Mn showed noticeably elevated contents in the shell. The high contents of Sr in both the body and shell (623 and $923 \mu \mathrm{g} \mathrm{g}{ }^{-1}$ dry w., respectively), reflect an important biochemical function of $\mathrm{Sr}$, that along with $\mathrm{Ca}$, serve as one of the constitutional elements. Note that for $\mathrm{Sr}, \mathrm{Ba}$, and $\mathrm{W}$, a difference in their contents in body and shell is small enough. Among the class of Anthozoa, we examined the two subclasses, Hexacorallia and Octocorallia. These specimens were analysed as whole bodies, without splitting individuals into compartments. In specimens of Zoantharia Hexacorallia, sampled at the northern summit, a high content of TOC (45.6\%) and 1.0\% TIC were detected (Table S1).

The element distribution in coral polyps Hexacorallia Zoantharia sampled both at the southern and northern tops, and Actiniaria, collected at the northern top of the Piip Volcano, is displayed in Figure 6. One can see, that in Zoantharia, particularly high contents ( $>100 \mu \mathrm{g} \mathrm{g}^{-1}$ dry w.) were detected for Fe and $\mathrm{Zn}$ in specimens from both sites. The Mn, $\mathrm{Fe}, \mathrm{Cr}, \mathrm{Ni}, \mathrm{Ag}, \mathrm{U}$, and particularly $\mathrm{Ba}$, showed higher concentrations in the specimens from the southern top, while the rest of the elements exhibited no significant difference between the two sampling sites.

In Actiniaria, the element distribution pattern, in terms of their concentration ranges, demonstrates a similarity to those for Zoantharia. The highest contents ( $>100 \mu \mathrm{g} / \mathrm{g}$ dry wt.) were detected for Fe and $\mathrm{Zn}$, however, the maximal Ba content in Zoantharia from the southern site (around $1000 \mu \mathrm{g} / \mathrm{g}$ dry wt) might be considered as its specific feature. At the same time, the lower contents of most elements (Ti, V, Mn, Fe, Co, Cu, Se, $\mathrm{Ag}, \mathrm{Cd}, \mathrm{Sb}, \mathrm{Pb}$, and $\mathrm{Bi}$ ) are characteristic of Actiniaria compared to Zoantharia.

The Anthozoa soft coral, Heteropolypus ritteri (Octocorallia: Alcyoniidae), and Corallimorpharia (Hexacorallia) inhabit areas closely located to hydrothermal vents on the southern top. Among the trace elements examined, Fe was found in the highest content (>400 $\mathrm{\mu g} \mathrm{g}^{-1}$ dry wt.) in whole bodies of both these taxa (Figure 7). 


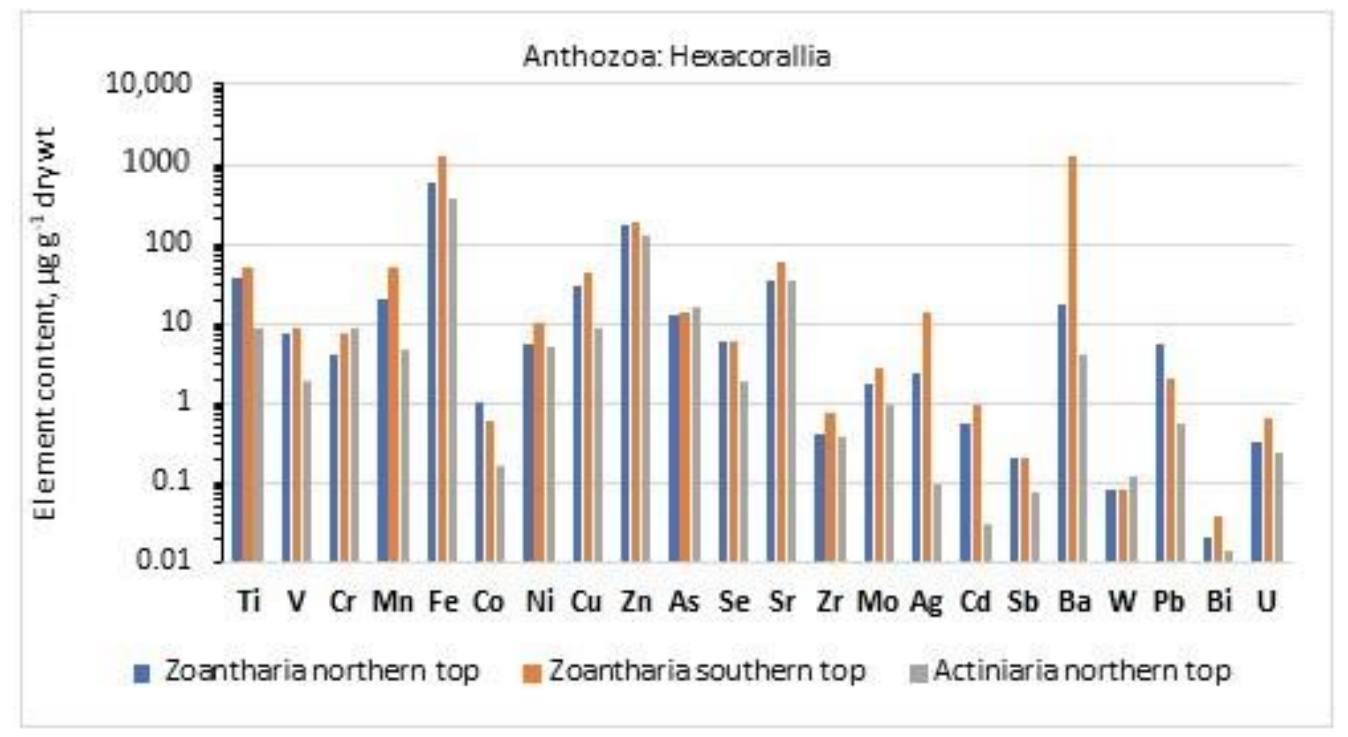

Figure 6. Distribution of elements in class Anthozoa: subclass Hexacorallia Zoantharia and Actiniaria.

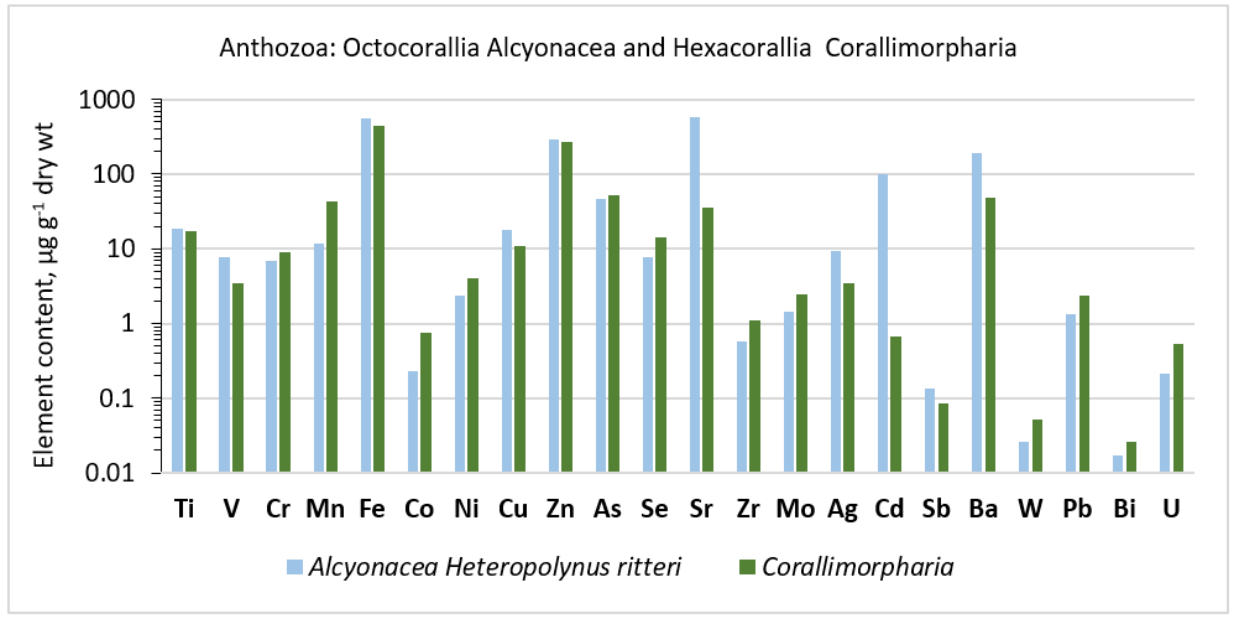

Figure 7. Distribution of elements in class Anthozoa: Heteropolypus ritteri (Octocorallia: Alcyonacea) and Corallinomorpharia (Hexacorallia).

By the analogy with Zoantharia and Actiniaria, a rather high concentration of Sr (556 $\mu \mathrm{g} \mathrm{g}^{-1}$ dry wt. on average), which are comparable with those for Fe and $\mathrm{Zn}$, were determined in the soft coral Alcyoniidae Heteropolypus ritteri that inhabited the southern top. In the latter, the average contents of TOC and TIC were $47.85 \%$ and $1.85 \%$, respectively. In this species, concentrations of $\mathrm{V}, \mathrm{Fe}, \mathrm{Cu}$, and particularly $\mathrm{Sr}, \mathrm{Ag}, \mathrm{Cd}$, and $\mathrm{Ba}$ were 2 to 100 times higher than in Corallimorpharia. The $\mathrm{V}, \mathrm{Mn}, \mathrm{Co}, \mathrm{Ni} \mathrm{Pb}, \mathrm{W}, \mathrm{Bi}$, and $\mathrm{U}$ in specimens of Corallimorpharia exhibited noticeably higher concentrations compared to Heteropolypus ritteri. The average concentrations of $\mathrm{Ti}, \mathrm{Cr}, \mathrm{Se}, \mathrm{Zr}, \mathrm{Mo}, \mathrm{Sb}$, and $\mathrm{Bi}$ in these two coral species were almost the same (Figure 7).

Specimens of Demospongia were collected on both the southern and northern tops of the Piip Volcano. Trace metal content in the seston and plankton feeder Demospongia were analysed in the whole body (Table S1). Among the elements, the content of Fe was the maximal one (584 $\mathrm{gg} \mathrm{g}^{-1}$ dry wt. on average) (Figure 8). The Sr and Ba are the elements whose concentrations exceeded $100 \mu^{-1} \mathrm{~g}^{-1}$ dry wt. in specimens from the northern top. It should be noted, that, unlike Zoantharia, the concentrations of most examined elements in Demospongia are higher at the northern top of the volcano. At the same time, the average contents of $\mathrm{Zn}, \mathrm{As}$, and $\mathrm{Cd}$ were higher in specimens from the southern top. 


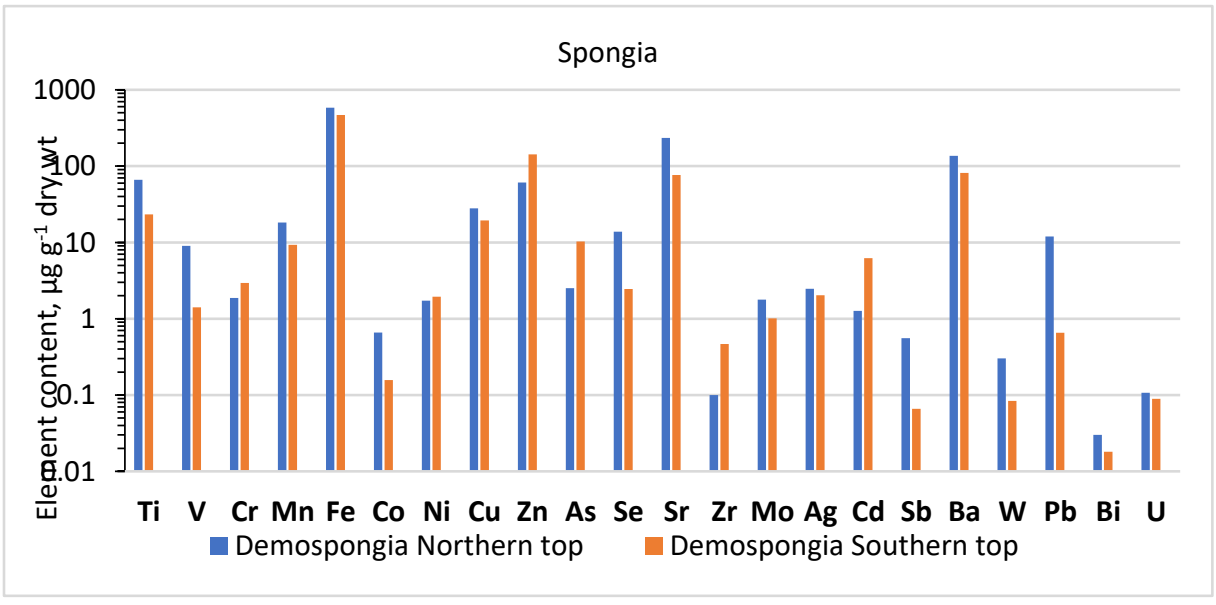

Figure 8. Distribution of elements in the Demospongia whole body's specimens inhabited the northern and southern tops of the Piip Volcano.

\subsubsection{Distribution of Trace Elements in the Organisms of Group 3}

Group 3 included two taxa of carnivores: Echinodermata (Asteroidea), and Crustacea (Paguridae and Chionoecetes opilio). These animals were collected on the southern top of the Piip Volcano, in addition, specimens of $C$. opilio were sampled in the background zone. For this study, we have examined the animals' whole bodies.

In group 3, the total organic carbon (TOC) with content exceeding 19\% is a major constituent (Table S1). However, the content of TOC is different in these taxa: Paguridae contains $19.33 \%$ TOC, while two specimens of Chionoecetes opilio-38.86\% and $32.67 \%$ in samples from different zones, affected by fluids and beyond it, respectively. On the contrary, Paguridae is enriched in total inorganic carbon (TIC) $(5.26 \%$ on average) relatively to two specimens of C. opilio ( $0.48 \%$ and $1.33 \%)$. A rather noticeable content of TIC in these crustaceans suggests a varying portion of $\mathrm{CaCO} 3$ ( 4 to $44 \%$ ) in their bodies. Carbonate structure provides a significant content of Sr (1000 to $2000 \mu \mathrm{g} \mathrm{g}^{-1}$ dry wt. on average), that serves as a biogeochemical analog of $\mathrm{Ca}$; a constitutional element for most organisms.

Very close concentration levels of most elements were detected in specimens of Asteroidea and Paguridae (Figure 9). The $\mathrm{Ni}, \mathrm{Cu}, \mathrm{Cd}$, and $\mathrm{U}$ content are noticeably increased in the body of Asteroidea compared to Paguridae.

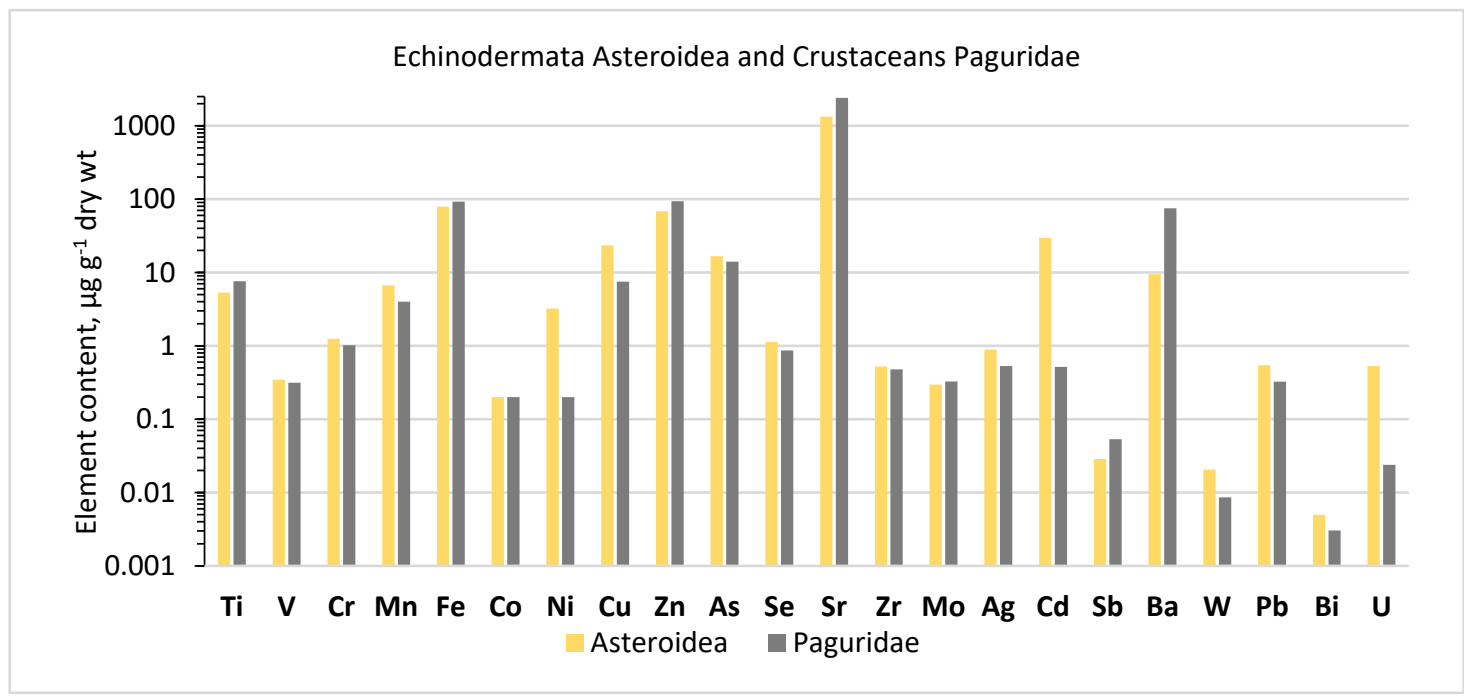

Figure 9. Distribution of elements in Asteroidea (Echinodermata) and Paguridae (Crustacea). 
The distribution of elements in crustacea Chionoecetes opilio exhibited the elevated contents of $\mathrm{V}, \mathrm{Cr}, \mathrm{Mn}, \mathrm{Co}, \mathrm{Ni}, \mathrm{Cu}, \mathrm{Ag}, \mathrm{Cd}$, and $\mathrm{U}$ in specimens from the southern top compared to those from the background zone (Figure 10). It implies an influence of the hydrothermal fluids, emitting at the southern top, upon the elemental composition of organisms.

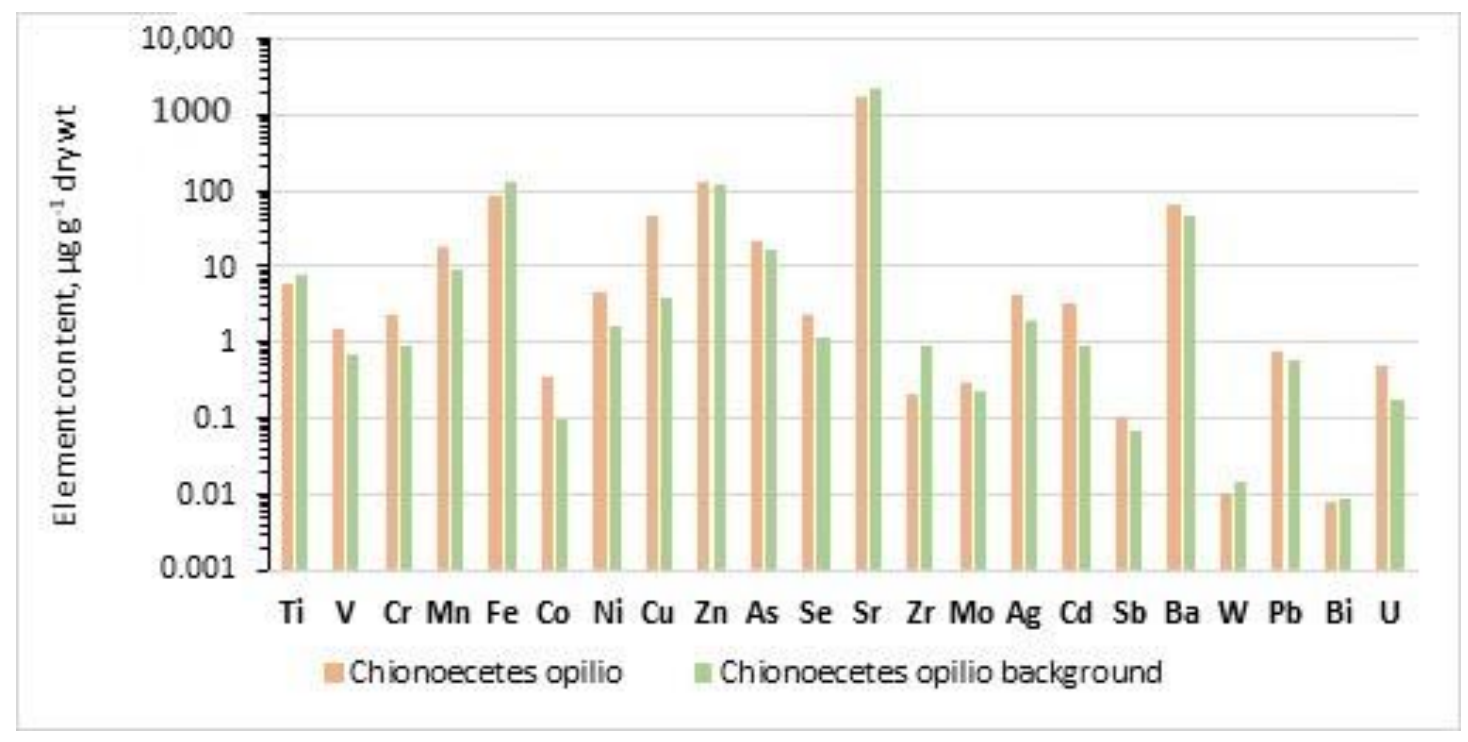

Figure 10. Distribution of elements in Chionoecetes opilio (Crustacea) inhabited zone, affected by hydrothermal fluids at the southern top of the Piip Volcano, and the background zone.

While comparing the two taxa of Crustaceans (Paguridae and Chionoecetes opilio), one could notice the close levels of concentrations of most elements, namely, $\mathrm{Ti}, \mathrm{Zn}, \mathrm{As}, \mathrm{Mo}, \mathrm{Sb}$, $\mathrm{W}, \mathrm{Pb}, \mathrm{Bi}$, and particularly, $\mathrm{Sr}$ and $\mathrm{Ba}$. At the same time, concentrations of $\mathrm{V}, \mathrm{Ni}, \mathrm{Ag}$, and $\mathrm{U}$ in Paguridae are noticeably lower than those in Chionoecetes opilio.

\subsection{Sediments}

The examined bottom deposits included three samples collected at different sites: at the foot of the active chimney at the northern top, from the settlements of Calyptogena pacifica and the background zone beyond the hydro-thermal influence at the southern top.

\subsubsection{Mineral Composition of Sediments}

Data on the XRD quantitative mineralogical analysis are listed in Table 3. Sediment from the active chimney's foot (LV 1) was presented by anhydrite (63\%) and gypsum (37\%).

Substratum of the Calyptogena pacifica (LV 8) is composed of calcite ( $89 \%)$, dolomite $(5 \%)$, and barite (3\%), with admixtures (to $2 \%$ ) of quartz and andesine. The XRD analysis of selected grains of different colours separated from the bulk sediment, demonstrated that the dark grains are quartz (39\%), andesine $(28 \%)$, smectite $(17 \%)$, heilandite $(8 \%)$, pyrite, and barite ( 5 and $3 \%$, respectively). The grey grains were identified as dolomite, talc, and calcite, while the light-grey grains were composed of calcite $(95 \%)$ and clay mineral smectite (5\%). The major constituent of background sediment (station LV 9) is calcite (94\%), with admixtures (to $1 \%$ of each) of quartz, andesine, amphibole, as well as the clay minerals (smectite, illite, and chlorite). 
Table 3. Mineral composition of sediment specimens from the active southern top of the Piip Volcano and from the background area.

\begin{tabular}{|c|c|c|c|c|c|c|}
\hline & \multicolumn{6}{|c|}{ Numbers of Samples } \\
\hline & LV 1 & LV 8 & LV 8 & LV 8 & LV 8 & LV 9 \\
\hline Minerals & $\begin{array}{c}\text { Sediment on Foot of Active } \\
\text { Anhydrite Chimney }\end{array}$ & $\begin{array}{l}\text { Calyptogena } \\
\text { Substratum }\end{array}$ & $\begin{array}{c}\text { Dark } \\
\text { Grains }\end{array}$ & $\begin{array}{l}\text { Grey } \\
\text { Grains }\end{array}$ & $\begin{array}{l}\text { Light-Grey } \\
\text { Grains }\end{array}$ & Background \\
\hline Quartz & & 1 & 39 & & & 1 \\
\hline Andesine & & 2 & 28 & & & 1 \\
\hline Amphibole & & & & & & 1 \\
\hline Barite & & 3 & 3 & & & \\
\hline Anhydrate & 63 & & & & & \\
\hline Calcite & & 89 & & 5 & 95 & 94 \\
\hline Dolomite & & 5 & & 89 & & \\
\hline Smectite & & & 17 & & 5 & 1 \\
\hline Illite & & & & & & 1 \\
\hline Chlorite & & & & & & 1 \\
\hline Pyrite & & & 5 & & & \\
\hline Gypsum & 37 & & & & & \\
\hline Talc & & & & 6 & & \\
\hline Heilandite & & & 8 & & & \\
\hline
\end{tabular}

\subsubsection{Elemental Composition of Sediments}

Data of ICP-MS analysis on the elemental composition of natural bulk sediments is provided in Table S3. The analyses of TOC demonstrated a strong depletion of sediments in organic carbon $(0.01 \%$ to $0.07 \%)$ for all three samples. A low TOC content is likely caused by the mineral composition of sediments, that contained the authigenic carbonates, volcanogenic and terrigenous material of the ice-rafted debris of different sizes. Such deposits are generally characterized by the low content of organic carbon. The TIC content was also low in the case of anhydrite deposits. On the contrary, sediments at the southern slope, from both C. pacifica's settlements and background zone, are enriched in TIC-9.55\% and $9.56 \%$, respectively (Table S3). The latter suggests a predominance of carbonate material $(79.6 \%)$ in sediments from the southern top, which is in rather good agreement with the data of the XRD mineralogical analysis.

In the anhydrite deposits, only three elements were detected in noticeable concentrations (ppm): $\mathrm{Sr}$ (2812), $\mathrm{Fe}$ (691), and Ba (62), while the rest of examined elements were detected in very low (10 to $1 \mathrm{ppm})$ and even negligible ( $<1 \mathrm{ppm})$ contents. In sediments from the C. pacifica's settlements, contents of all the elements exceeded noticeably those from the anhydrite deposits and background zone (Table S3).

Since carbonate material constitutes a significant proportion of the sediment from the southern top, we have calculated concentrations of elements on the carbonate-free base $(\mathrm{cfb})$. The average values of element content in sediments calculated on the carbonate-free base in comparison to the Upper Continental Crust (UCC), as well the Enrichment factor's values, are listed in Table 4. 
Table 4. Elemental composition (carbonate free base) of the bottom deposits at the southern tops of the Piip Volcano in comparison to the Upper Continental Crust (UCC), and the Enrichment Factor (EF) values.

\begin{tabular}{|c|c|c|c|c|c|}
\hline Element & $\begin{array}{c}\text { C. Pacifica's Substratum, } \\
\text { Southern Top }\end{array}$ & $\begin{array}{l}\text { Background Sediment, } \\
\text { Southern Top }\end{array}$ & UCC * & $\begin{array}{c}\mathrm{EF} \\
\text { C. pacifica's Substratum }\end{array}$ & $\begin{array}{l}\text { EF Background } \\
\text { Sediment }\end{array}$ \\
\hline $\mathrm{Al}$ & 7961 & 2946 & 81,620 & - & - \\
\hline $\mathrm{Ti}$ & 2235 & 815 & 3800 & 6.0 & 5.9 \\
\hline $\mathrm{V}$ & 260 & 55 & 97 & 27.5 & 15.7 \\
\hline $\mathrm{Cr}$ & 200 & 60 & 92 & 22.3 & 18.1 \\
\hline $\mathrm{Mn}$ & 10,235 & 5100 & 770 & 135 & 182 \\
\hline $\mathrm{Fe}$ & 35,240 & 16,960 & 35,300 & 9.2 & 12.0 \\
\hline $\mathrm{Co}$ & 13.5 & 6 & 17.3 & 8.0 & 9.6 \\
\hline $\mathrm{Ni}$ & 54.5 & 24 & 56 & 11.9 & 14.1 \\
\hline $\mathrm{Cu}$ & 135 & 32.5 & 28 & 49.4 & 32.2 \\
\hline $\mathrm{Zn}$ & 9605 & 540 & 67 & 1470 & 223 \\
\hline As & 318 & 5 & 4.8 & 679 & 29 \\
\hline Se & 56 & 5 & 0.09 & 6379 & 1539 \\
\hline $\mathrm{Zr}$ & 40.5 & 16 & 193 & 2,2 & 2,3 \\
\hline Mo & 34 & 3 & 1.1 & 317 & 76 \\
\hline $\mathrm{Ag}$ & 52.5 & 1.9 & 00.53 & 10,156 & 993 \\
\hline $\mathrm{Cd}$ & 30 & 5 & 0.09 & 3417 & 1539 \\
\hline $\mathrm{Sb}$ & 26 & 1.5 & 0.4 & 666 & 104 \\
\hline $\mathrm{Ba}$ & 100,395 & 5990 & 628 & 1639 & 264 \\
\hline $\mathrm{W}$ & 2 & 0.5 & 1.9 & 10.8 & 7.3 \\
\hline $\mathrm{Pb}$ & 25 & 6.5 & 17 & 15.1 & 10.6 \\
\hline $\mathrm{Bi}$ & 0.15 & 0.1 & 0.16 & 9.6 & 17.3 \\
\hline $\mathrm{U}$ & 112 & 27 & 2.7 & 425 & 277 \\
\hline
\end{tabular}

From Table 4, it can be seen that contents of most elements in sediments from settlements of $C$. pacifica are 2 to 300 times higher than those in the UCC, particularly in the case of $\mathrm{Ag}, \mathrm{Zn}, \mathrm{Cd}$, and $\mathrm{Ba}$ (100 to 300 times). At the same time, contents of $\mathrm{Ti}, \mathrm{V}, \mathrm{Fe}, \mathrm{Ni}, \mathrm{Co}$, $\mathrm{Pb}, \mathrm{Bi}$, and $\mathrm{W}$ in the substratum of $\mathrm{C}$. pacifica are of the same order of magnitude as those in UCC. An Enrichment Factor (Al-normalized contents compared to Upper Continental Crust $(\mathrm{UCC})[40])$ from Equation $\mathrm{EF}=\left[(\mathrm{X} / \mathrm{Al})_{\text {sample }} /(\mathrm{X} / \mathrm{Al})_{\mathrm{UCC}}\right]$. In general, $\mathrm{EF}>3$ indicates a detectable level of the authigenic enrichment, and EF> 10 represents the values varying from moderate to strong enrichments [41]. From Table 4, it is seen that bottom sediments from both zones, seep area with C. pacifica settlements and background, are enriched by most elements and depleted by the only one element, zirconium $(\mathrm{EF}<3)$. In the seep sediments, a moderate enrichment $(\mathrm{EF}<10)$ was found for $\mathrm{Ti}, \mathrm{Fe}, \mathrm{Co}$, and $\mathrm{Bi}$, while $\mathrm{Mn}, \mathrm{Cr}, \mathrm{V}, \mathrm{Cu}, \mathrm{Zn}, \mathrm{As}, \mathrm{Se}, \mathrm{Mo}, \mathrm{Ag}, \mathrm{Cd}, \mathrm{Sb}, \mathrm{Ba}$, and $\mathrm{U}$ displayed a strong enrichment $(\mathrm{EF}>10)$. Among these metals, the strongest enrichment of the seep sediments (EF > 1000) was detected for $\mathrm{Zn}$, Se, Mo, $\mathrm{Ag}, \mathrm{Cd}$, and $\mathrm{Ba}$. While comparing $\mathrm{EF}$ values between the seep and background sediments, the $\mathrm{Ti}, \mathrm{Cr}, \mathrm{Mn}, \mathrm{Fe}, \mathrm{Co}, \mathrm{Ni}, \mathrm{Zr}, \mathrm{W}$, and Bi showed no significant difference (Figure 11). So, a direct influence of hydrothermal diffused fluids on the sediment enrichment does not seem to be evident for all the elements examined. 


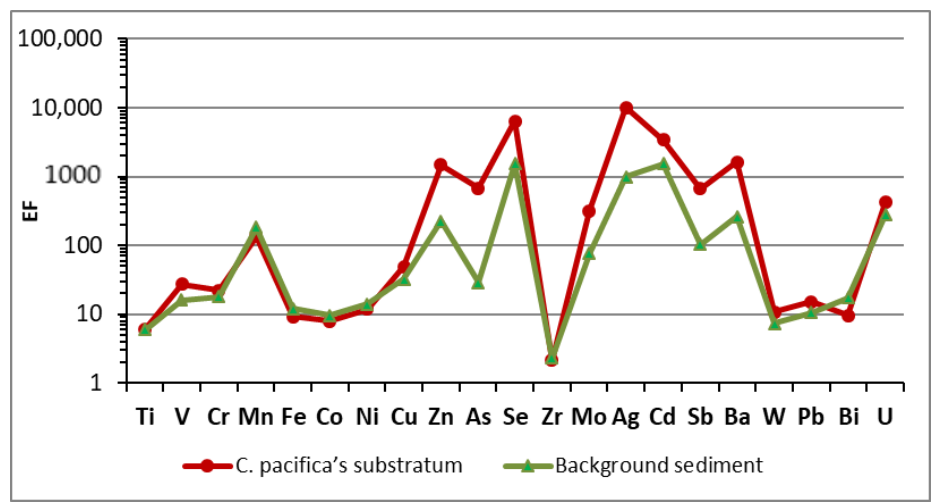

Figure 11. Distribution of Enrichment Factor (EF) in the C. pacifica settlement' substratum and background sediments from the Piip Volcano's southern top.

\subsection{Biotope Water}

The concentrations of elements in the biotope water sampled at two tops of the Piip Volcano are displayed in Table S2 and Figure 12. Amongst the elements, the Fe and Mn concentrations are much higher (10 to 104 times) compared to the rest of the elements. One can see that in the biotope water at the northern top, concentrations of $\mathrm{Mn}, \mathrm{Zn}, \mathrm{Ag}, \mathrm{Cd}$, $\mathrm{Sb}, \mathrm{W}, \mathrm{Pb}$ are 2 to 6 times, and $\mathrm{Ba}-50$ times higher than those at the southern top. This corresponds to the higher temperature of outflowing fluids from the vent at the northern top $\left(132.79^{\circ} \mathrm{C}\right)$ compared to the southern one $\left(10.59^{\circ} \mathrm{C}\right)$. The high-temperature hydrothermal vent fluids at the Mid-Atlantic Ridge are enriched with dissolved barium, whose isotopes show evidence for non-conservative behaviour, and barite is rapidly precipitated during mixing between Ba-bearing vent fluids and SO4-bearing seawater [42]. However, in the areas influenced by the diffused low-temperature fluids of the Piip Volcano, by our data, the dominant mineral in the C. pacifica's substrate was calcite rather than barite (Table 3). We have recorded the highest concentrations of Ba in bacterial mats $\left(4000 \mathrm{\mu g} \mathrm{g}^{-1}\right)$ underlying the $C$. pacifica settlement, that supported the Ba intensive accumulation by bacterial biofilms composed of the extracellular polymeric substances (EPS) described in [42]. For the majority of examined elements, a difference between the northern and southern tops is insignificant. It should be noted that the element distribution pattern is very close in two tops (Figure 12). On the other hand, the biotope water is highly enriched in most elements (as much as 5 to 1000 times), relatively those for the ocean water (Table S2). The exceptions are Mo and Sr, the concentrations of which in both biotopes are almost equal to ocean water, as well as $\mathrm{Ba}$, whose concentrations in the ocean water and biotope from the southern top are of the same order of magnitude.

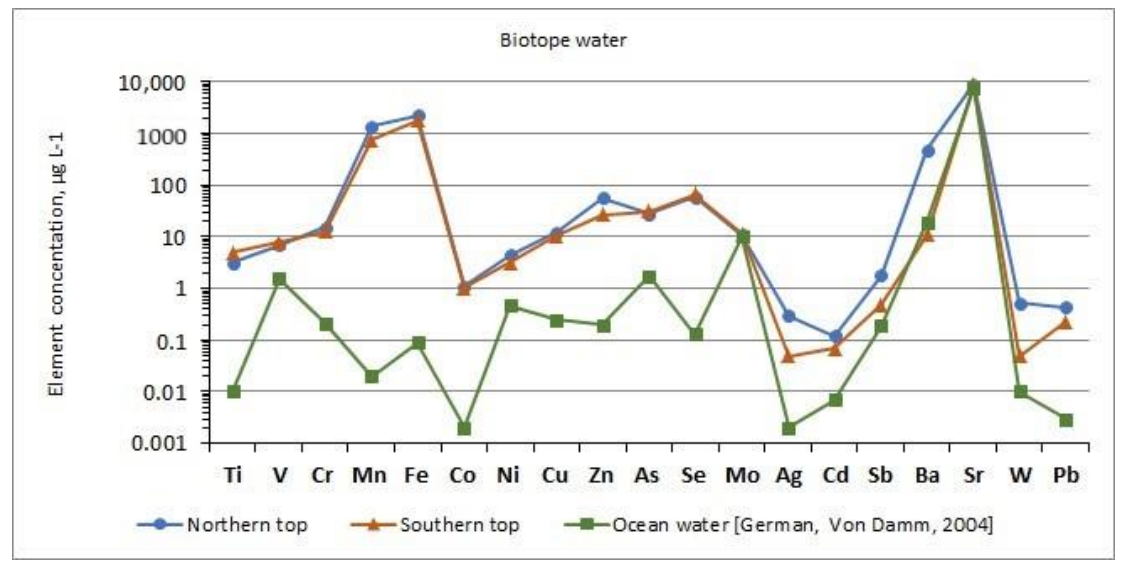

Figure 12. Trace element concentrations in the biotope water at the northern and southern tops of the Piip Volcano compared to the ocean water [5]. 


\section{Discussion}

Knowledge of element concentrations, and particularly heavy metals and their variations in bottom organisms, are essential for the understanding of bioaccumulation and detoxification strategies. Many trace elements participate in the key biochemical processes [43,44]. Various factors influence the element bioaccumulation, including the exposure regime, bioavailability of elements, issues related to different biology of species, and others. The trace elements under consideration might be referred to a few different groups by their biogeochemical significance. The iron is one of the most abundant elements in the lithosphere [40], as well as in the hot reduced hydrothermal solutions [1]. At the same time, in the oxygenated ocean water, dissolved Fe was detected in the trace concentrations $(\leq 1.5 \mathrm{nmol})$ [44] and recognized as a key element for phytoplankton functioning $[45,46]$. The $\mathrm{Co}, \mathrm{Ni}, \mathrm{Cd}, \mathrm{Cr}, \mathrm{Cu}, \mathrm{Zn}$, Se, and $\mathrm{As}$, are well known to be the bio-essential trace metals showing a similar to the nutrients vertical distribution pattern reflecting a change in primary productivity in the ocean water [44]. In the water of hydrothermal biotope, Fe and other heavy metals are strongly complexed by organic matter $[6,47,48]$. The methane and sulphide oxidizing bacterial consortium need heavy metals $\mathrm{Cr}, \mathrm{Fe}, \mathrm{Co}$, and $\mathrm{W}$, as co-ferments for catalysing biochemical processes $[49,50]$. The less dissoluble elements-hydrolysates, such as $\mathrm{Ti}$, and $\mathrm{Zr}$, have no established biochemical function to date, moreover, along with many heavy metals, they are known to be toxic for the organisms when exceeded a certain concentration threshold [51-53].

Our data on the three groups of organisms inhabiting the southern and northern tops of the Piip Volcano, suggest a great variability in element concentrations among taxa, as well as a rather large range of the same element in different groups of organisms (Table S1).

Considering a distribution pattern of different groups of benthic organisms (Figures 3 and 5-10), one can notice a general decrease trend in the trace element concentration's level from group 1 (specialized symbiotrophic clams) to group 3 (detritus feeder and carnivores), a common phenomenon described earlier [17,18,21].

\subsection{Trace Elements' Targets in the Bottom Fauna}

It is of interest to reveal target organisms and tissues/organs, where the concentration of each element is much higher compared to the others, as well as those depleted in elements (Table 4). The main target of most trace elements, such as $\mathrm{Fe}, \mathrm{V}, \mathrm{Cr}, \mathrm{Co}, \mathrm{Ni}, \mathrm{Zn}, \mathrm{As}$, $\mathrm{Mo}, \mathrm{Ag}, \mathrm{Cd}, \mathrm{W}, \mathrm{Pb}, \mathrm{Bi}$, and $\mathrm{U}$ are gills and the rest of the body of Calyptogena pacifica. The high content of total organic carbon (TOC) was found in the C. pacifica gills and the rest of the soft body (53.1\% and $49.6 \%$, respectively) (Table S1), which is considerably higher than in other organisms examined. The C. pacifica's carbonate shell is depleted in these elements, as well as crustacea Paguridae and Actiniaria, however, in the whole body of Paguridae, the average content of TOC was elevated $(19.33 \%$, Table S1).

In Bivalve, gills are the organ directly involved in feeding and respiratory metabolism. Numerous chemoautotrophic sulphur-oxidizing bacteria, housed in hypertrophied gills of $C$. pacifica, produce the main part of organic matter necessary for molluscs. It means that gills are the organ where intensive processes of organic matter synthesis and uptake of organics by molluscs occur. Bacterial consortium requests heavy metals to catalyse oxidation of sulphides and methane in a reduced environment [49]. The trace metals are present in $\sim 50$ microbial enzymes involved in microbial S cycling [50]. So, a complexation with organic ligands, produced by a bacterial consortium in chemosynthetic metabolism, might promote the highest accumulation of trace metals primary in the C. pacifica gills, as well as in its soft tissues (including digestive glands). Generally, a high level of trace metal concentration was typical for symbiotrophic taxa, reflecting the high concentration of metals in the biotope water influenced by vent fluids [18-25]. Another reason for the high concentrations of heavy metals is their chalcophile, i.e., an affinity to form sulfidic mineral phases or to associate with them. Gills of symbiotrophic clams retain the ability to filter. Thus, sulphide micro-and nanoparticles generated while the fluids mixed with seawater and dispersed in the biotope water could be filtered from via clam's gills and 
stored there. Earlier, such a possibility was revealed for the deep-sea hydrothermal vent symbiotrophic mussel Bathymodiolus, in whose gills pyrite $\left(\mathrm{FeS}_{2}\right)$ and wurtzite $\left(\mathrm{ZnS}_{2}\right)$ were detected by X-ray diffraction analysis [19,23]. A comparison of the elements' distribution pattern in gills of $C$. pacifica and bacterial mat (Figure 4) revealed that gills are enriched in $\mathrm{Cr}, \mathrm{Co}, \mathrm{Ni}, \mathrm{Zn}, \mathrm{Se}, \mathrm{Mo}, \mathrm{Ag}, \mathrm{Cd}, \mathrm{Pb}$, and $\mathrm{Bi}$ (most of these elements refer to chalcophiles). The metal uptake in the form of mineral particles has been identified as their important source in the mussel tissues $[17,25,26]$.

In the bacterial mat, composed not only of alive microorganisms but of biomineral particles, the contents of $\mathrm{Ti}, \mathrm{Mn}, \mathrm{Sr}, \mathrm{Zr}, \mathrm{Ba}$, and $\mathrm{U}$ are noticeably higher than in gills; these elements are considered as lithogenous and constitutional ones. From this, we suggest that the chalcophile elements are likely concentrated in gills mainly due to the specificity of their functioning.

The Mn demonstrated strongly elevated contents in the Brachiopoda shell, that is enriched in calcareous substance (11.9\% TIC, Table S1); the minimum Mn contents were found in Actiniaria, and Paguridae. A preferable Mn accumulation in carbonate shells versus soft tissues in symbiotrophic mussel Bathymodioulus sp. was observed earlier at the deep-sea hydrothermal vent sites of the Mid-Atlantic Ridge [19]. The Sr exhibited a similar tendency to associate with carbonate biostructures, whose target was C. pacifica's shell, and the whole bodies of crustaceans Paguridae and Chionoecetes (with TOC contents $19.33-38.86 \%$, Table S1). The Sr predominant accumulation in carbonate shell is reasonably caused by the isomorphic substitution of $\mathrm{Ca}^{2+}$ ion by $\mathrm{Sr}^{2+}$ ion which has a similar Ca ionic radius: 1.26 and $1.00 \AA$, respectively [54].

In the soft tissues of Brachiopoda, Se and $\mathrm{Zr}$ were found in elevated concentrations. Demospongia was found to be a target for Ti and $\mathrm{Sb}$. In the case of Ba and As, targets were Zoantharia (Anthozoa) and Corallimorpharia (Anthozoa), respectively. Note, that the soft coral Zoantharia is enriched in TOC $(45.6 \%$, Table S1).

From these observations, we can note a trend to an increased concentration of most elements ( $\mathrm{Fe}, \mathrm{V}, \mathrm{Cr}, \mathrm{Co}, \mathrm{Ni}, \mathrm{Zn}, \mathrm{As}, \mathrm{Mo}, \mathrm{Ag}, \mathrm{Cd}, \mathrm{W}, \mathrm{Pb}, \mathrm{Bi}, \mathrm{Ba}, \mathrm{Ti}, \mathrm{Sb}$, and $\mathrm{U}$ ) in organisms and tissues with elevated contents of TOC. At the same time, their lower content was found not only in the shell (lower TOC contents), but in organisms that belong to higher trophic levels, such as Zoantharia and Crustaceans Paguridae, in whose body TOC contents are also rather high. This might be attributed to the general trend of decreasing trace element concentrations with increasing trophic levels.

\subsection{Concentration Function of the Bottom Fauna}

The trace metals are known to be accumulated in different organs of marine organisms coming from the water in the course of metabolic processes and during feeding and respiration. The concentration function of the hydrothermal fauna depends on many factors, one of them is a level of concentration of an element in the biotope water. In seawater, $\mathrm{Mn}, \mathrm{Zn}, \mathrm{Cu}, \mathrm{Cd}, \mathrm{Pb}, \mathrm{Co}, \mathrm{Cr}, \mathrm{Ni}$, and $\mathrm{Ba}$, occur in a bioavailable form of divalent cations. $\mathrm{Mo}, \mathrm{U}, \mathrm{As}$, and $\mathrm{V}$ occur as oxyanions that are soluble in the oxygenated environment but become insoluble and precipitated under anaerobic conditions. In hydrothermal fluids, heavy metals usually occur in the dissolved form [5,53,54].

The vent zone is known as the most spatially heterogeneous environment of the deepsea high-temperature field, resulting in the formation of a geochemical barrier with steep gradients of the physical and chemical parameters; there, within a few tens of centimetres from a vent, temperature decreases by tens of ${ }^{\circ} \mathrm{C}$, while $\mathrm{pH}$ values increase from $2-3$ to 5.6-6.8 [5,55-57]. Despite a dilution of hydrothermal vent fluids with the ocean water, the biotope water at the Piip Volcano is strongly enriched in trace elements relative to ocean water, as was shown on Figure 12.

Numerous investigations of the deep-sea hydrothermal sites at the Middle-Atlantic Ridge and East-Pacific Rise demonstrated that as a rule, concentrations of elements in mussel tissues reflect the elements' loads in the biotope. The biological communities demonstrate a strong concentration function that is reflected in high values of the bio- 
concentration factor (BCF). For estimation of a bioconcentration factor, the following equation is commonly used.

$\mathrm{BCF}=\mathrm{Ci}$ organ $/ C \mathrm{i}_{\text {water, }}$, where $\mathrm{Ci}$ organ is a concentration of i-element in the selected organism or its organs, $\mathrm{Ci}_{\text {water }}$ is a concentration of $\mathrm{i}$-element in the water of the biotope. So, for Bathymodiolus mussels collected from the four Mid-Atlantic Ridge (MAR) hydrothermal fields, BCF was estimated at n102-n105 and these values are similar to those for the littoral mussels $[18,58]$.

Based on data from Tables S1 and S2 (trace element contents in organisms and biotope water, respectively), the BCF values were estimated for C. pacifica, as well as for suspension feeders Brachiopoda, Zoantharia, and Demospongia (Table S4). As was mentioned above, we analysed not only dissolved elements, but the total dissoluble elements. Storage of water samples at $\mathrm{pH} 2$ prevents adsorption of trace elements on the vial's inner walls, as well as provides a dissolution of the labile fraction of suspended particles. The latter consists of various microparticles composed of the mineral (with the exception of terrigenous ones) and organic substances. It should be noted that the labile fraction may serve as a diet for the suspension feeding bottom organisms. So, the BCF values that we calculated are the approximate estimates, that in fact are lower than those values that could be obtained taking into account only the dissolved fraction of metals (since the lower concentration of an element in the biotope water, the higher its BCF value, in accordance with the calculation formula). The BCF values for C. pacifica and suspension-feeders are displayed in Figures 13-16.

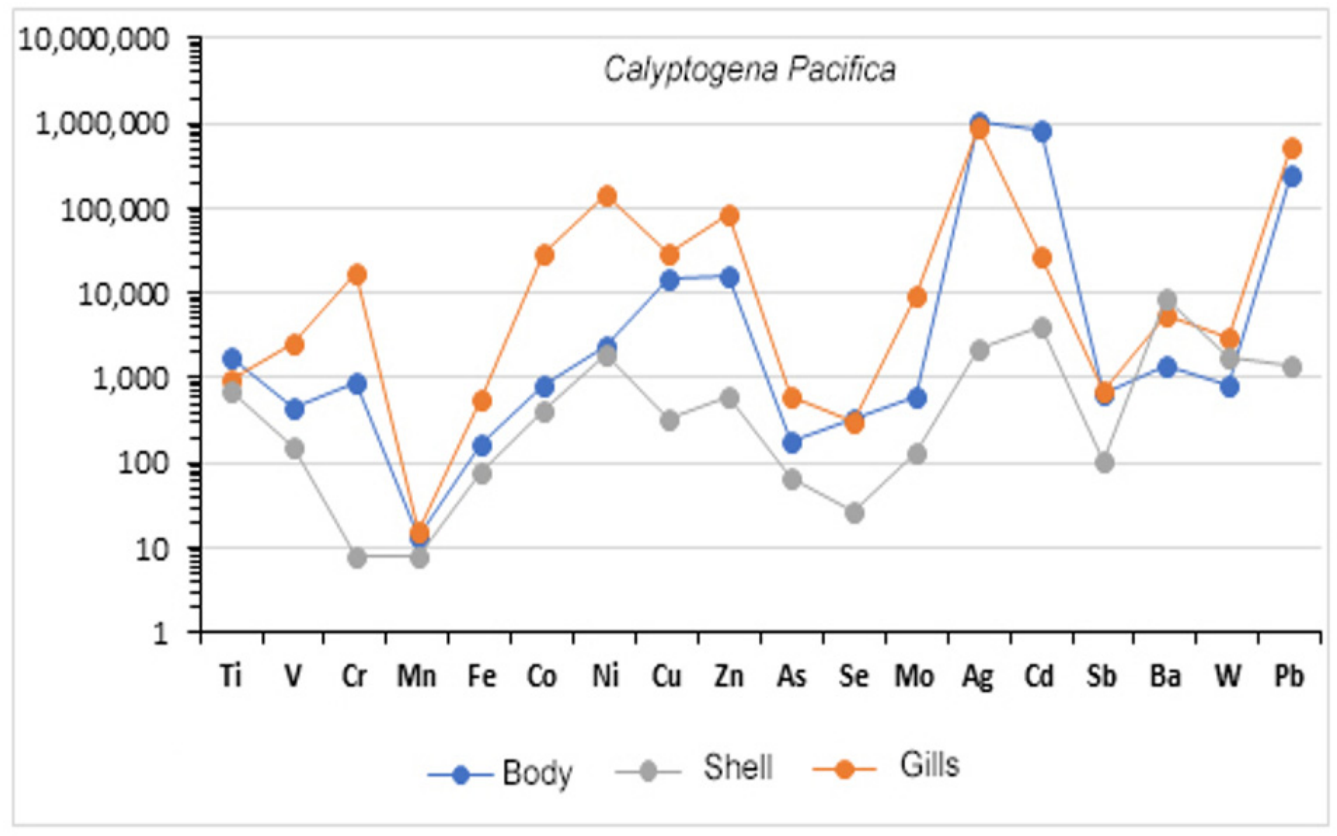

Figure 13. Distribution pattern of the trace element BCF in gills, the rest of soft body, and shell of C. pacifica.

At the Piip Volcano's southern top, C. pacifica is one of the most abundant and dominant species whose feeding strategy relies on bacterial symbiotrophy, which functionally depends on the reduced compounds of the fluids $[29,30]$. The highest $B C F$ values $\left(10^{6}-10^{5}\right)$ were detected for $\mathrm{Ni}, \mathrm{Cu}, \mathrm{Zn}, \mathrm{Ag}, \mathrm{Cd}$, and $\mathrm{Pb}$ in the $\mathrm{C}$. pacifica's gills and body. For all the elements (except $\mathrm{Mn}$ and $\mathrm{Ba}$ ), the minimal accumulation was observed in C. pacifica's shell. The $\mathrm{Mn}$ is the only element with the minimal BCF (around 10) in all three selected parts (Figure 13).

An ability of most elements to enhanced accumulation in soft tissues of organisms appeared to be characteristic not only for symbiotrophic clam C. pacifica, but for suspensionfeeder Brachiopoda. From Figure 14, it could be seen that in the soft body, all the elements 
(except $\mathrm{Mn}$ and $\mathrm{Fe}$ ) accumulated 5 to 100 times more than in the shell. In soft body tissues of Brachiopoda, the BCF values reach a maximum (up to $10^{6}$ ) for $\mathrm{Ag}$ and $\mathrm{Cd}$, for most of the elements, BCF ranged $10^{2}-10^{4}$, while the lowest BCF values $\left(<10^{2}\right)$ were detected for $\mathrm{Mn}$ and, in the case of the shell, for Se. In the case of suspension feeder Anthozoa Zoantharia, the elevated $\mathrm{BCF}$ values $\left(>\mathrm{n} 10^{3}\right)$ were detected for $\mathrm{Ag}, \mathrm{Cd}, \mathrm{Cu}, \mathrm{Zn}, \mathrm{Ni}, \mathrm{Pb}$, and Ti. For most of the elements, BCF ranged $10^{2}-10^{3}$, while the lowest $B C F$ values $\left(<10^{2}\right)$ were detected for Mn, and for Se (in case of shell).

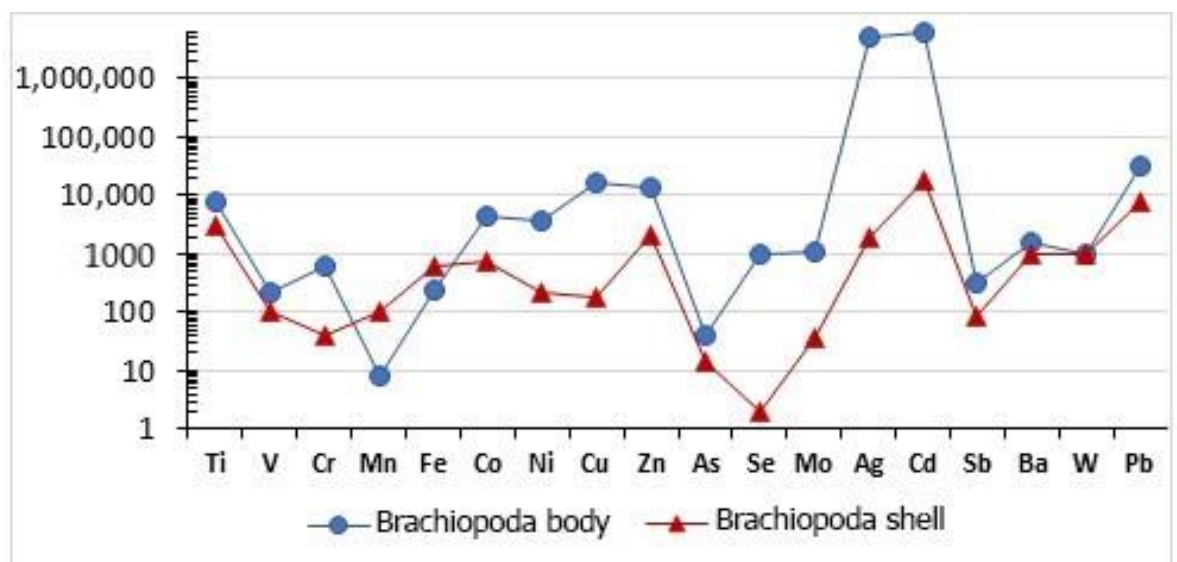

Figure 14. Distribution pattern of the trace element BCF in body and shell of Brachiopoda.

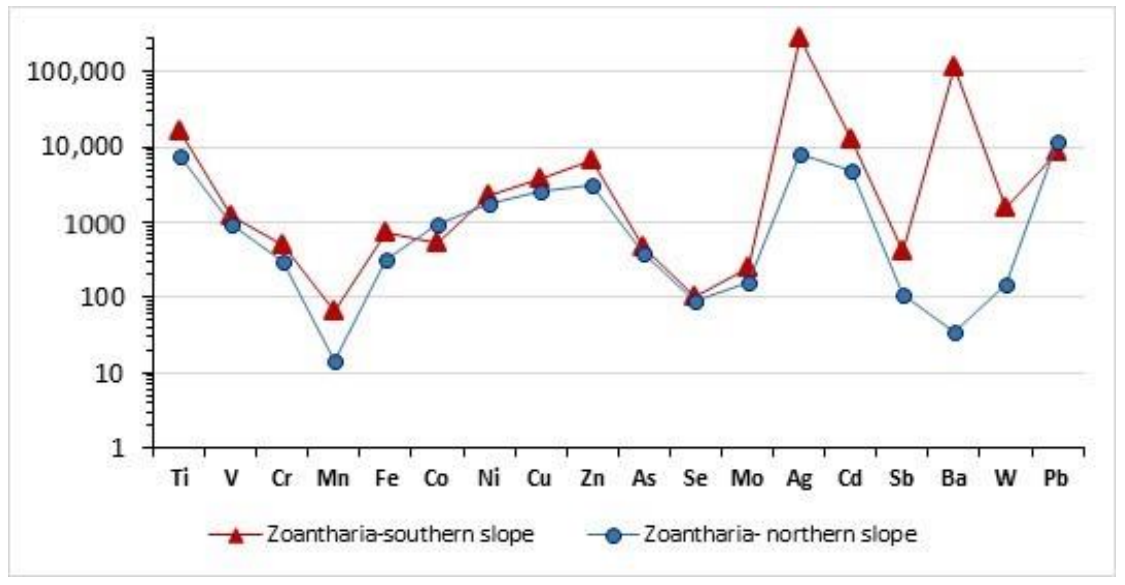

Figure 15. Distribution pattern of the trace element BCF in Zoantharia (Anthozoa). 


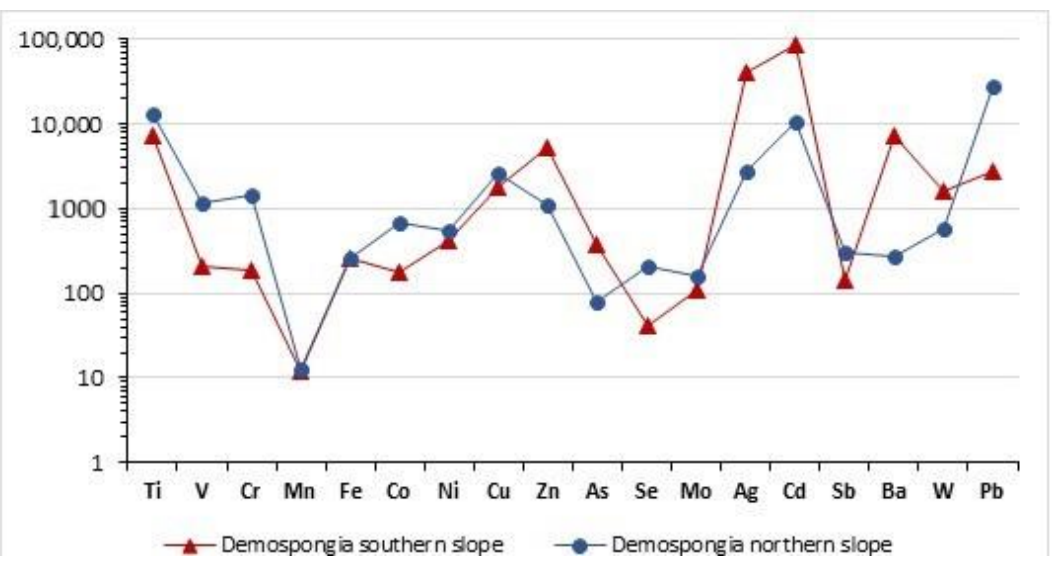

Figure 16. Distribution pattern of the trace element BCF in the whole body of Demospongia collected on the southern and northern tops of the Piip Volcano.

As was mentioned above, in the biotope water at the northern top, where "the white smoker" ( $\mathrm{T}^{\circ}$ of fluids was up to $132.79{ }^{\circ} \mathrm{C}$ ) was discovered [29,30], concentrations of $\mathrm{Zn}$, $\mathrm{Sb}, \mathrm{Ba}, \mathrm{Ag}, \mathrm{Cd}$, and $\mathrm{W}$ were significantly higher than those from the southern top (Table S2, Figure 12), where temperature was much lower (to $10.59^{\circ} \mathrm{C}$ ). At the same time, the $\mathrm{BCF}$ values of most elements for Anthozoa Zoantharia, collected at the northern top, are close or much lower compared to the those from the southern top (Figure 15). Unlike these, the bioaccumulation of $\mathrm{Ag}$ and Ba differs strongly in both cases: the BCF values were maximal for $\mathrm{Ag}$ and $\mathrm{Ba}\left(\mathrm{n} 10^{5}\right)$ in specimens from the southern top. In specimens of Zoantharia on the southern top, $\mathrm{BCF}$ of $\mathrm{Ti}, \mathrm{Ni}, \mathrm{Cu}, \mathrm{Zn}, \mathrm{Ag}, \mathrm{Cd}$, and $\mathrm{Pb}$ were $>10^{3}$. So, the differences in the concentration of elements in the water of the biotopes of both tops of the volcano do not appear to determine an increase in accumulation in that biotope where there are more metals in the water. On the other hand, due to significantly higher concentrations of $\mathrm{Ba}$ in biotope water on the northern top than on the southern top (485 and $11 \mu \mathrm{g} / \mathrm{L}$, respectively), it is natural that BCF for Ba in Zoantharia from southern top is much lower than that in southern specimens (in accordance with the definition for BCF calculation). The $\mathrm{Mn}$, the $\mathrm{BCF}$ values of which ranged from 10 to $10^{2}$, demonstrated the minimum accumulation in Zoantharia.

A similar trend could be seen for the BCF distribution in the case of the Demospongia specimens collected at the southern and northern tops (Figure 16). A common feature in the element accumulation in Zoantharia and Demospongia is that the higher BCF values are revealed for such elements as $\mathrm{Ag}, \mathrm{Cd}, \mathrm{Pb}, \mathrm{Ba}, \mathrm{Zn}, \mathrm{Cu}, \mathrm{Cr}$, and $\mathrm{Ti}$, which are known to be strongly assimilated by marine phyto- and zooplankton [59]. The Fe and $\mathrm{Mn}$ are crucially important for the living organisms, and from our data, they dominate in the biotope water revealing the highest concentration compared to the rest of the elements (Table S2, Figure 12). However, their BCF values in Demospongia are different: BCF for $\mathrm{Mn}$ is 20-50 times less than for Fe. Moreover, amongst all the elements, the BCF values for Mn are minimal at both tops (Figure 16).

From Figure 12, one can see the following order of the element concentrations' decrease in the biotope water: $\mathrm{Fe}, \mathrm{Mn}>\mathrm{Ba}>\mathrm{Se}>\mathrm{Zn}>\mathrm{As}>\mathrm{Cr}, \mathrm{Cu}, \mathrm{Mo}>\mathrm{V}>\mathrm{Ni}, \mathrm{Ti}>\mathrm{Co}>\mathrm{Sb}>\mathrm{Pb}>\mathrm{Cd}$, $\mathrm{Ag}>\mathrm{W}$. At the same time, our data (Table S1, Figures 3 and 5-10) demonstrated that for the element concentrations in organisms, such a sequence was relevant only for $\mathrm{Fe}$, the content of which was higher compared to the other examined trace elements (Sr was not included since it does not belong to trace elements). For the rest of the elements, first of all, for $\mathrm{Mn}$, this order was changed. Moreover, Mn displayed the lowest (20 to 50 times) BCF values compared to those of $\mathrm{Fe}$ for most examined organisms (Figures 13-16). A similar disproportion in bioaccumulation of Fe and Mn by the deep-sea hydrothermal fauna was observed earlier [60]. This might imply that the bioaccumulation of elements occurs not directly, but indirectly depending not only on their total content in the biotope water but 
mainly on the chemical element speciation, and the latter determines a bioavailability. An important role of the organic complexes of $\mathrm{Fe}, \mathrm{Cu}$, and the other heavy metals in their flux from hydrothermal vents was evidenced $[6,47,48]$. Heavy metals in the biotope water are associated with the complexes of dissolved amino acids, that stabilize their precipitation and thus promote increasing the flow of metals from vents into the ocean $[6,47,48]$. Considering that in the biotope water, the $\mathrm{Mn}$ and Fe total dissoluble concentrations are of the same order of magnitude (Table S2), we might forward a hypothesis about a very low bioavailability of Mn for the organisms in the biotope water of the Piip Volcano. To confirm these observations, a special analysis of the Mn occurrence forms of elements in the biotope water should be carried out.

The trace metals' speciation is an important factor that determines their biological availability and via this, their bioaccumulation. A significant proportion of elements are taken from the water through permeable surfaces, i.e., gills. This pathway depends on the speciation of dissolved metals, including hydrophilic and/or hydrophobic properties of metal complexes [56]. Accumulation of trace elements on the outer organs (shell and carapace), as well as on the whole body of benthic organisms, results also from adsorption. In the deep-sea hydrothermal fields, the occurrence forms are controlled by not only a simple dilution of fluids but more complicated processes, such as an additional and/or secondary formation of suspended solid phase when fluids are mixed with seawater [55-57]. Non-conservative behaviour of $\mathrm{Fe}, \mathrm{Zn}, \mathrm{Cu}$, and $\mathrm{Pb}$ in the mixing zone of fluids and water at the $13^{\circ} \mathrm{N}$, the East Pacific Rise was revealed, resulting in the formation of suspended particulate matter ( $>2 \mu \mathrm{m}$ size). In different hydrothermal sites, sulphides were presented by pyrite $(\mathrm{Fe})$, sphalerite $(\mathrm{Zn})$, and chalcopyrite $(\mathrm{Cu})$ [17].

\subsection{Correlation Relationships between Elements}

Results of the Spearman correlation analysis between the examined elements in the organisms as a whole are listed in Table S5. The significant correlation coefficients (R2, $p<0.05)$ was obtained for the following pairs of ore elements: Fe-V, 0.85; Fe-Mo, 0.76; Fe-W, 0.68; Fe-Pb, 0.66; Fe-Ti, 0.63; Fe-Co, 0.60; Fe-Cr, 0.55; Cu-Cr, 0.72; Cu-Ni, 0.70; Ni-Cr, 0.68; Ni$\mathrm{Co}, 0.61$; Cu-Co, 0.58; Cu-Pb, 0.72; Zn-Pb, 0.65; Co-Pb, 0.85; Pb-V, 0.73; Pb-Mo, 0.78; Pb-Cd, 0.56 ; TOC-TIC, 0.64 . These values indicate a direct positive relationship in the accumulation of most heavy metals in the organisms. A significant negative relationship was revealed for pairs: $\mathrm{Cr}$-TIC, 0.55 ; $\mathrm{Cu}-\mathrm{TIC},-0.51$. The $\mathrm{Sr}$, being a biogeochemical analogue of $\mathrm{Ca}$, is accumulated in carbonate biomineral structures, demonstrated a negative correlation with many heavy metals: $\mathrm{Sr}-\mathrm{Cr},-0.70 ; \mathrm{Sr}-\mathrm{V},-0.65 ; \mathrm{Sr}-\mathrm{Fe},-0.61 ; \mathrm{Sr}-\mathrm{Pb},-0.56$; $\mathrm{Sr}-\mathrm{Zn},-0.54$; Sr-U, -0.54; Sr-W, $-0.51 ;$ Sr-Mo, -0.50 . These are heavy metals that are accumulated in soft body tissues rather than in carbonate shells. It should be noted that there is no relationship in the accumulation of $\mathrm{Sr}$ and $\mathrm{Ba}(\mathrm{R} 2 \mathrm{Sr}-\mathrm{Ba}, 0.07)$.

\subsection{Similarity of Different Groups of Organisms Based on Results of HCA (Hierarchial Cluster Analysis)}

The organisms examined and their tissues were grouped by similarity of their chemical composition (the content of TOC, TIC, and 22 trace elements) based on the hierarchical cluster analysis (HCA). Ward's method was chosen as a way to combine data in the cluster analysis [38]. The distance between the clusters is represented in the form of Euclidean distance. As a result, seven clusters (I-VII) were formed that are presented in the form of a dendrogram in Figure 17. 


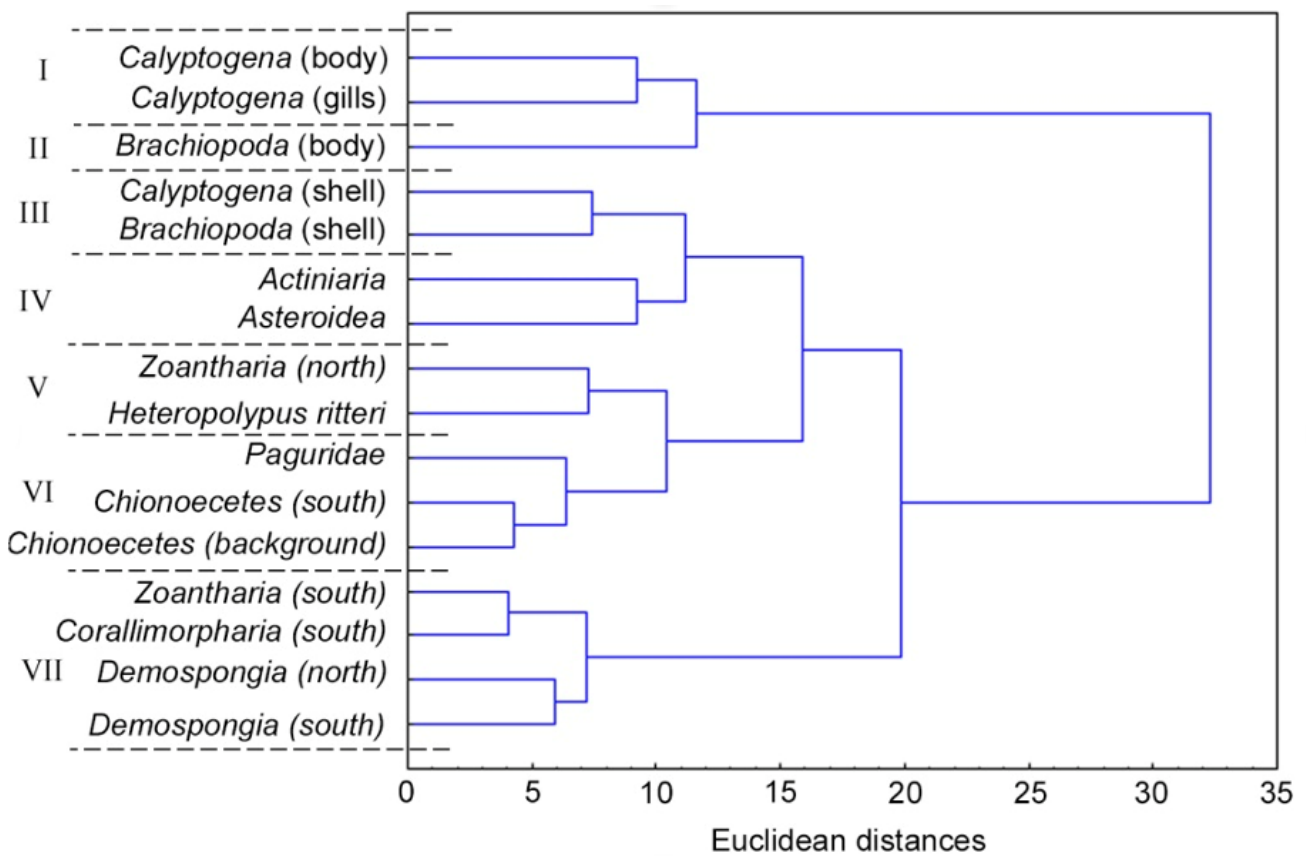

Figure 17. Dendrogram of relationship between trace element accumulation in different groups of bottom organisms inhabiting the Piip Volcano tops.

The clusters I and II form a separate branch on the dendrogram, which joins organisms with the greatest concentration function among the organisms studied. Cluster I include body tissues and gills of the symbiotrophic Bivalvia Calyptogena pacifica, which has the maximum content of most of the studied elements. A separate cluster (II) includes the body tissues of Brachiopoda, in which the maximum content of $\mathrm{Cu}$, Se, and $\mathrm{Sr}$ are recorded. Cluster III (carbonate) combines the shells of the clam Calyptogena and Brachiopoda. It is quite natural that carbonate shells are enriched with TIC, and they have a low content of most trace elements, except for the Mn whose content in the Brachiopoda shell reaches $70.5 \mu \mathrm{g} \mathrm{g}^{-1}$.

Despite the difference in the feeding types, Actiniaria coral polyps and Asteroidea starfish are combined into one cluster IV, due to the common features of their elemental composition. In general, these organisms are characterized by a low content of trace elements, and therefore in the dendrogram, they are close to Cluster III (carbonate). Cluster V consists of coral polyps Zoantharia collected on the northern top of the Piip Volcano, and soft corals Heteropolypus ritteri. Cluster VI is formed by Crustaceans; hermit crab Paguridae and crab Chionoecetes opilio, which differ in feeding type (detritus feeder and carnivores, respectively) from the other organisms. At the same time, Chionoecetes opilio, collected both on the southern summit of the volcano, and in the background area, shows no differences in the trace element content in their bodies depending on the habitat. Coral polyps Zoantharia and Corallimorpharia (Anthozoa), as well as the sponge Demospongia from the northern and southern summits of the volcano are grouped into Cluster VII. These are the organisms of the same feeding type (seston feeders) that have similar elemental composition and $\mathrm{BCF}$ values.

\section{Conclusions}

The twenty-two elements' distribution in the three selected groups of the benthic organisms, as well as in the abiotic components was studied for the first time in the submarine Piip Volcano ecosystem. Our data showed no selectivity in the accumulation of exclusively the bioessential heavy metals, the toxic metals are also accumulated. In the different taxa, the trace element concentration varied within five orders of magnitude $\left(10^{-2}\right.$ to $\left.10^{3} \mu \mathrm{g} \mathrm{g}^{-1}\right)$. A target of bioaccumulation for chalcophile metals $\mathrm{Fe}, \mathrm{Co}, \mathrm{Zn}, \mathrm{Cd}$, $\mathrm{Ni}, \mathrm{Cu}, \mathrm{Ag}, \mathrm{Mo}$, and $\mathrm{Pb}$ was found to be the C. pacifica gills and the rest of the soft body 
where the highest TOC content was detected. Numerous chemoautotrophic sulphuroxidizing bacteria, housed in hypertrophied gills of Calyptogena, produce the main part of organic matter necessary for molluscs. It means that gills are the organ where intensive processes of organic matter synthesis and uptake of organics by molluscs occur. For the active metabolism, both bacteria and bivalve molluscs may need some trace elements participating in the processes of respiration, cell lysis, synthesis, and activation of enzymes, thus promoting an elevated concentration of trace elements in gills. Along with it, gills have a larger area of contact with the ambient seawater and a more intense exchange between the external environment and internal of the body. That might lead to a retention of the dispersed sulphide microparticles in gills while filtering and aspiration.

A depletion of the above elements is characteristic of carbonate shells of $C$. pacifica and Brachiopoda. In contrast, $\mathrm{Mn}$ and Sr exhibited a larger accumulation with carbonate biostructures. Earlier, we observed a preferable Mn association with carbonate shells versus soft tissues of symbiotrophic mussel Bathymodioulus sp. at the deep-sea hydrothermal vent sites of the Mid-Atlantic Ridge.

The hydrothermal fluids are the main source of chemical elements for the biocommunities of the Piip Volcano. According to our data, the biotope water is highly enriched in most elements compared to the typical ocean water. The biotope water at the northern volcano's top, with the higher temperature fluids emanating from the vent $\left(132.7^{\circ} \mathrm{C}\right)$ is characterized by the higher concentrations of $\mathrm{Ba}, \mathrm{Mn}, \mathrm{Zn}, \mathrm{Ag}, \mathrm{Cd}, \mathrm{Sb}, \mathrm{W}$, and $\mathrm{Pb}$, than those at the southern top where the temperature of vent fluids was much lower $\left(10.6^{\circ} \mathrm{C}\right)$. Amongst the elements, $\mathrm{Fe}$ and $\mathrm{Mn}$ show the highest concentrations (on average 2200 and $1250 \mu \mathrm{g} \mathrm{l}^{-1}$, correspondingly) which are 10-10 times higher compared to the other elements. However, despite the same order of magnitude for Fe and $\mathrm{Mn}$ in the biotope water, their average content in examined organisms differs significantly. The estimated $\mathrm{BCFs}$, which characterize the element accumulation relatively in the environment water, are 20-50 times less for $\mathrm{Mn}$ than for Fe. It could be attributed to a different bioavailability that is related to different chemical speciation of $\mathrm{Fe}$ and $\mathrm{Mn}$ in the biotope water. In the soft tissues of organisms, the BCF values ranged from $10^{2}$ to $10^{4}$ for most elements, reaching the maximum (up to $\mathrm{n} 10^{6}$ ) for $\mathrm{Ag}$ and $\mathrm{Cd}$, while the lowest $\mathrm{BCF}$ values $\left(<10^{2}\right)$ were detected for $\mathrm{Mn}$.

The elemental and mineral composition of sediments from the studied area suggested an influence of the hydrothermal fluids. Sediments from C. pacifica's bed are enriched $(\mathrm{EF}>3)$ in all the examined elements (besides $\mathrm{Zr}$ ) relative to the background sediments. This allows us to consider sediments as a source of accumulation of many elements for benthos feeders, as well as for suspension feeders (due to resuspension of surface bottom sediments induced by bottom current).

Based on the hierarchical cluster analysis (HCA), the organisms and their tissues were grouped in seven clusters by similarity of their elemental composition. As a whole, these clusters correspond to the above selected three groups of organisms that differ in the nutrition type. The organisms of the same feeding group are characterized by similar levels of the element concentration, as well as by the close BCF estimates.

Supplementary Materials: The following are available online at https:/ / www.mdpi.com/article / $10.3390 / \min 11111233 / \mathrm{s} 1$. Table S1: The average elements' concentrations ( $\mu \mathrm{g} / \mathrm{g}$ dry weight) in bottom organisms and their tissues collected at the southern and northern tops of the Piip Volcano; Table S2: The average element concentrations ( $\mu \mathrm{g} / \mathrm{L})$ in the biotope water of the Piip Volcano; Table S3: Contents of total organic carbon (TOC), total inorganic carbon (TIC), $\mathrm{CaCO}$, and elements in bottom deposits at the northern and southern tops of the Piip Volcano; Table S4: The elements' bioconcentration factor (BCF) in the two groups of benthic organisms inhabiting tops of the Piip Volcano; Table S5: The Spearman correlation coefficients for the organisms inhabiting the Piip Volcano tops.

Author Contributions: L.L.D. interpreted the geochemical results, wrote the text; S.V.G. carried out sampling, interpreted the biological data, wrote the text; E.M.K. performed the taxonomy determination, wrote the text; D.F.B. performed the statistical analysis; A.S.S. performed chemical 
treatment of samples the ICP-MS analysis. All authors have read and agreed to the published version of the manuscript.

Funding: The research was funded by the Ministry of Science and Higher Education, Russian Federation (grant 13.1902.21.0012, contract No 075-15-2020-796).

Institutional Review Board Statement: Not applicable.

Informed Consent Statement: Not applicable.

Data Availability Statement: Not applicable.

Acknowledgments: The authors are grateful to the captain and crew of cruise $83 \mathrm{R} / \mathrm{V}$ Akademik M.A. Lavrentyev for assistance in the sampling process; the underwater photos made by ROV Comanche 18 courtesy of Zhirmunsky National Scientific Center of Marine Biology, DVO RAS, Vladivostok. We thank D.P. Starodymova for the measurements of the element concentrations in the water, sediments and fauna by the ICP-MS analysis and to N.A. Belyaev for performing TOC and TIC analysis (both from from Shirshov Institute of Oceanology, RAS, Moscow).

Conflicts of Interest: The authors declare no conflict of interests.

\section{References}

1. Edmond, J.M.; Von Damm, K.L.; McDuff, R.E.; Measures, C.I. Chemistry of hot springs on the East Pacific Rise and their affluent dispersal. Nature 1982, 297, 187-191. [CrossRef]

2. Rona, P.A. Hydrothermal mineralization at seafloor spreading centers. Earth Sci. Rev. 1984, 20, 1-104. [CrossRef]

3. James, R.H.; Elderfield, H.; Palmer, M.R. The chemistry of hydrothermal fluids from the Broken Spur site, 29 N Mid-Atlantic Ridge. Geochim. Cosmochim. Acta 1995, 59, 651-659. [CrossRef]

4. Elderfield, H.; Schulz, A. Mid-ocean ridge hydrothermal fluxes and the chemical composition of the ocean. Annu. Rev. Earth Planet. Sci. 1996, 24, 191-224. [CrossRef]

5. German, C.R.; Von Damm, K.L. Hydrothermal Processes. In Treatise on Geochemistry; Holland, H.D., Turekian, K.K., Elderfield, H., Eds.; The oceans and marine geochemistry; Elsevier Pergamon: Amsterdam, The Netherlands, 2004; Volume 6, pp. 181-222.

6. Sander, S.G.; Koschinsky, A. The Export of Iron and Other Trace Metals from Hydrothermal Vents and the Impact on Their Marine Biogeochemical Cycle. In Trace Metal Biogeochemistry and Ecology of Deep-Sea Hydrothermal Vent Systems Handbook of Environmental Chemistry; Demina, L.L., Galkin, S.S., Eds.; Springer International Publishing: Cham, Switzerland, 2016; Volume 50, pp. 9-24. [CrossRef]

7. Tagliabue, A.; Bopp, L.; Dutay, J.C.; Bowie, A.R.; Chever, F.; Jean-Babtiste, P.; Bucciarelli, E.; Lannuzel, D.; Remenyi, T.; Sarthou, G.; et al. Hydrothermal contribution to the oceanic dissolved iron inventory. Nat. Geosci. 2010, 3, 252-256. [CrossRef]

8. Yucel, M.; Gartman, A.; Chan, C.S.; Luther, G.W. Hydrothermal vents as a kinetically stable source of iron-sulphide-bearing nanoparticles to the ocean. Nat. Geosci. 2011, 4, 367-371. [CrossRef]

9. Nishioka, J.; Obata, H.; Tsumune, D. Evidence of an extensive spread of hydrothermal dissolved iron in the Indian Ocean. Earth Planet Sci. Lett. 2013, 361, 26-33. [CrossRef]

10. Conway, T.M.; John, S.G. Quantification of dissolved iron sources to the North Atlantic Ocean. Nature 2014, 511, $212-215$. [CrossRef] [PubMed]

11. German, C.R.; Legendre, L.L.; Sander, S.G.; Niquil, N.; Luther, I.G.W.; Bharati, L.; Han, X.; Le Bris, N. Hydrothermal Fe cycling and deep ocean organic carbon scavenging: Model-based evidence for significant POC supply to seafloor sediments. Earth Planet Sci. Lett. 2015, 419, 143-153. [CrossRef]

12. Resing, J.A.; Sedwick, P.N.; German, C.R.; Jenkins, W.J.; Moffett, J.W.; Sohst, B.M.; Tagliabue, A. Basin-scale transport of hydrothermal dissolved metals across the South Pacific Ocean. Nature 2015, 523, 200-203. [CrossRef] [PubMed]

13. Jannasch, H.W.; Wirsen, G.O. Chemosynthetic Primary Production at East Pacific Sea Floor Spreading Centers. Bioscience 1979, 79, 592-598. [CrossRef]

14. Desbruyères, D.; Segonzac, M. Handbook of Deep-Sea Hydrothermal Vent Fauna; IFREMER: Brest, France, $1997 ;$ p. 279.

15. Desbruyères, D.; Almeida, A.; Biscoito, M.; Comtet, T.; Khripounoff, A.; Le Bris, N.; Sarradin, P.M.; Segonzac, M. A review of the distribution of hydrothermal vent communities along the northern Mid-Atlantic Ridge: Dispersal vs. environmental control. Hydrobiologia 2000, 440, 201-216. [CrossRef]

16. Galkin, S.V. Hydrothermal Vent Communities of the World Ocean. Structure, Typology, Biogeography; GEOS: Moscow, Russia, 2002; p. 199. (In Russian)

17. Kádár, E.; Costa, V.; Martins, I.; Santos, R.S.; Powell, J.J. Enrichment in trace metals (Al, Mn, Co, Cu, Mo, Cd, Fe, Zn, Pb and Hg) of the macro-invertebrate habitats at hydrothermal vents along the Mid-Atlantic Ridge. Hydrobiology 2005, 548, 191-205. [CrossRef]

18. Kádár, E.; Costa, V.; Segonzac, M. Trophic influences of metal accumulation in natural pollution laboratories at deep-sea hydrothermal vents of the Mid-Atlantic Ridge. Sci. Total Environ. 2007, 373, 464-472. [CrossRef]

19. Demina, L.L.; Galkin, S.V. On the role of abiogenic factors in the bioaccumulation of heavy metals by the hydrothermal fauna of the Mid-Atlantic Ridge. Oceanology 2008, 48, 784-797. [CrossRef] 
20. Demina, L.L.; Galkin, S.V. Factors Controlling the Trace Metal Distribution in Hydrothermal Vent Organisms. In Trace Metal Biogeochemistry and Ecology of Deep-Sea Hydrothermal Vent Systems Handbook of Environmental Chemistry; Springer International Publishing: Cham, Switzerland, 2016; Volume 50, pp. 123-142. [CrossRef]

21. Demina, L.L.; Holm, N.G.; Galkin, S.V.; Lein, A.Y. Some features of the trace metal biogeochemistry in the deep-sea hydrothermal vent fields (Menez Gwen, Rainbow, Broken Spur at the MAR and 9 ${ }^{\circ} 50^{\prime} \mathrm{N}$ at the EPR): A synthesis. J. Mar. Syst. 2013, 126, 94-105. [CrossRef]

22. Roesijadi, G.; Crecelius, E.A. Elemental composition of the hydrothermal vent clam Calyptogena magnifica from the East Pacific Rise. Mar. Biol. 1984, 83, 155-161. [CrossRef]

23. Colaso, A.; Bustamante, P.; Fouquet, Y.; Sarradin, P.M.; Serro-Santos, R. Bioaccumulation of Hg, Cu, and Zn in the Azores triple junction hydrothermal vent fields food web. Chemosphere 2006, 65, 2260-2267. [CrossRef] [PubMed]

24. Kadar, E.; Santos, R.S.; Powell, J.J. Biological factors influencing tissue compartmentalization of trace metals in the deep-sea hydrothermal vent bivalve Bathymodiolus azoricus at geochemically distinct vent sites of the Mid-Atlantic Ridge. Environ. Res. 2006, 101, 221-229. [CrossRef]

25. Koschinsky, A.; Kausch, M.; Borowski, C. Metal concentrations in the tissues of the hydrothermal vent mussel Bathymodiolus: Reflection of different metal sources. Mar. Environ. Res. 2014, 95, 62-73. [CrossRef]

26. Koschinsky, A. Sources and Forms of Trace Metals Taken Up by Hydrothermal Vent Mussels, and Possible Adaption and Mitigation Strategies. In Trace Metal Biogeochemistry and Ecology of Deep-Sea Hydrothermal Vent Systems Handbook of Environmental Chemistry; Springer International Publishing: Cham, Switzerland, 2016; Volume 50, pp. 97-122. [CrossRef]

27. Sagalevich, A.M.; Torokhov, P.V.; Matveenkov, V.V.; Galkin, S.V.; Moskalev, L.I. Hydrtothermal manifestation of the underwater Piip Volcano (the Bering Sea). Izvestiya RAS Geolog. Ser. 1992, 9, 104-114.

28. Krylova, E.M.; Sahling, H. Recent bivalve molluscs of the genus Calyptogena (Vesicomyidae). J. Molluscan Stud. 2006, 72, 359-395. [CrossRef]

29. Galkin, S.V.; Ivin, V.V. Biological Investigations in the Bering Sea Using a Remote Operated Vehicle Comanche. Oceanology 2019, 59, 170-172. [CrossRef]

30. Galkin, S.V.; Krylova, E.M.; Mordukhovich, V.V.; Denisov, V.A.; Malyutin, A.N.; Shilov, V.A.; Ivin, V.V.; Adrianov, A.V.; Mikhailik, P.E.; Polonik, N.S.; et al. Comprehensive research of ecosystems of hydrothermal vents and cold seeps in the Bering Sea (cruise 82 of the r/v Akademik, M.A. Lavrentyev). Oceanology 2019, 59, 618-621. [CrossRef]

31. Bogdanova, O.Y.; Gorshkov, A.I.; Baranov, B.V. Hydrothermal deposits of the submarine Piip Volcano (Komandor Depression). Volcanol. Seismol. 1989, 3, 49-62.

32. Torokhov, P.V. Sulfide mineralization of hydrothermal deposits of the submarine Piip Volcano (the Bering Sea). Doklady Earth Sci. 1992, 326, 1060-1063.

33. Seliverstov, N.I.; Torokhov, P.V.; Baranov, B.V. Submarine Piip Volcano; structural-tectonics control, geological setting, and hydrothermal activity. Volcanol. Seismol. 1995, 2, 50-71.

34. Seliverstov, N.I. The Seabed Structure of the Kamchatka Water Areas and the Geodynamics of the Joint Area of the Kurilo-Kamchatka and Aleutian Island Back-Arcs; Science World: Moscow, Russia, 1998; p. 164.

35. Kasakabe, M.; Mayeda, S.; Nakamura, S.S. The $\mathrm{O}$ and Sr isotope systematics of active vent materials from the Mariana back-arc basin spreading axis at $18^{\circ}$ N. Earth Planet. Sci. Lett. 1990, 100, 275. [CrossRef]

36. Bogdanov, Y.A.; Lisitzin, A.P.; Sagalevich, A.M.; Gurvich, E.G. Hydrothermal Ore Formation at the Ocean Floor; Nauka: Moscow, Russia, 2006; 527pp.

37. Polonik, N.S. Methane in water samples and hydrothermal fluids of the submarine Piip Volcano. Complex research of the World Ocean. In Proceedings of the 2nd All-Russian Scientific Conference of Young Researches, Moscow, Russia, 10-14 April 2017; pp. 578-579.

38. Ward, J.H. Hierarchical grouping to optimize an objective function. J. Am. Statist. Assoc. 1963, 58, 236-244. [CrossRef]

39. Martinez-Ruiz, F.; Jroundi, F.; Paytan, A.; Guerra-Tschuschke, I.; Abad, M.D.M.; González-Muñoz, M.T. Barium bioaccumulation by bacterial biofilms and implications for Ba cycling and use of Ba proxies. Nat. Commun. 2018, 9, 1619. [CrossRef]

40. Rudnick, R.L.; Gao, S. Composition of the continental crust. In Treatise on Geochemistry; Holland, H.D., Turekian, K.K., Eds.; Elsevier Pergamon: Amsterdam, The Netherlands, 2003; pp. 1-64.

41. Algeo, T.J.; Tribovillard, N. Environmental analysis of paleoceanographic systems based on molybdenum-uranium covariation. Chem. Geol. 2009, 268, 211-225. [CrossRef]

42. Hsieh, Y.-T.; Bridgestock, L.; Scheuermann, P.P.; Seyfried, W.E.; Henderson, G.M. Barium isotopes in mid-ocean ridge hydrothermal vent fluids: A source of isotopically heavy Ba to the ocean. Geochim. Cosmochim. Acta 2021, 292, 348-363. [CrossRef]

43. Bowen, H.J.M. Trace elements in biological samples. In Nuclear Analytical Techniques in Medicine; Cesareo, R., Ed.; Elservier: Amsterdam, The Netherlands, 1988; pp. 1-17.

44. Bruland, K.W.; Lohan, M.C. Controls of trace metals in sea water. In Treatise on Geochemistry, The Oceans and Marine Geochemistry; Holland, H.D., Turekian, K.K., Eds.; Elsevier: Amsterdam, The Netherlands, 2004; Volume 6, pp. $23-47$.

45. De Baar, H.J.W.; De Jong, J.T.M.; Bakker, D.C.E.; Veth, C.; Bathmann, U.; Smetacek, V. Importance of iron for plankton blooms and carbon dioxide drawdown in the South Ocean. Nature 1995, 373, 412-415. [CrossRef]

46. Martin, J.H.; Fitzwater, S.E.; Gordon, R.M. Iron deficiency limits phytoplankton growth in Antarctic waters. Glob. Biogeochem. Cycles 1990, 4, 5-12. [CrossRef] 
47. Sander, S.G.; Koschinsky, A.; Massoth, G.; Sexott, M.; Hunter, K.A. Organic complexation of Cu in deep-sea hydrothermal vent systems. Environ. Chem. 2007, 4, 81-89. [CrossRef]

48. Sander, S.G.; Koschinsky, A. Metal flux from hydrothermal vents increased by organic complexation. Nat. Geosci. 2011, 4, 145-150. [CrossRef]

49. Glass, J.B.; Hang, Y.; Steele, J.A.; Dawson, K.S.; Sun, S.; Chourey, K.; Chongle Pan, C.; Hettich, R.L.; Orphan, V.J. Geochemical, metagenomic and metaproteomic insights into trace metal utilization by methane-oxidizing microbial consortia in sulfidic marine sediments. Environ. Microbiol. 2014, 16, 1592-1611. [CrossRef]

50. Zhang, Y.; Gladyshev, V.N. Comparative genomics of trace elements: Emerging dynamic view of trace element utilization and function. Chem. Rev. 2009, 109, 4828-4861. [CrossRef]

51. Rainbow, P.S. Biomonitoring of heavy metal availability in the marine environment. Mar. Pollut. Bull. 1995, 31, 183-192. [CrossRef]

52. Crommentuijn, T.; Polder, M.D.; van der Plassche, E.J. Maximum Permissible Concentration and Negligible Concentration for Metals, Taking Background Concentration into Account; National Institute of Public Health and the Environment: Bilthoven, The Netherlands, 1997; p. 260.

53. Fuentes, V.; Alurralde, G.; Meyer, B.; Aguirre, G.E.; Canepa, A.; Wölfl, A.C.; Hass, A.C.; Williams, G.N.; Schloss, I. Glacial melting: An overlooked threat to Antarctic krill. Sci. Rep. 2016, 6, 27234. [CrossRef] [PubMed]

54. Skinner, H.C.W.; Jahren, A.H. Biomineralization. In Treatise on Geochemistry; Holland, H.D., Turekian, K.K., Eds.; Elsevier: Amsterdam, The Netherlands, 2004; pp. 117-181.

55. Sarradin, P.M.; Lannuzel, D.; Waeles, M.; Crassons, P.; Le Bris, N.; Caprais, J.C.; Fouquet, Y.; Fabri, M.C.; Riso, R. Dissolved and particulate metals $(\mathrm{Fe}, \mathrm{Zn}, \mathrm{Cu}, \mathrm{Cd}, \mathrm{Pb})$ in two habitats from active hydrothermal field on the EPR at $13^{\circ} \mathrm{N}$. Sci. Total Environ. 2008, 392, 119-129. [CrossRef] [PubMed]

56. Sarradin, P.M.; Waeles, M.; Bernagout, S.; Le Gall, C.; Sarrazin, J.; Riso, R. Speciation of dissolved copper within an active hydrothermal edifice on the Lucky Strike vent field (MAR, 37 N). Sci. Total Environ. 2009, 407, 869-878. [CrossRef] [PubMed]

57. Sarradin, P.M.; Caprais, J.C.; Riso, R.; Kerouel, R.; Aminot, A. Chemical environment of the hydrothermal mussel communities in the Lucky Strike and Menez Gwen vent fields. Mid-Atl. Ridge. Cah. De Biol. Mar. 1999, 40, 93-104.

58. Demina, L.L.; Gordeev, V.V.; Galkin, S.V.; Kravchishina, M.D.; Aleksankina, S.P. Biogeochemistry of some heavy metals and metalloids at transect the Ob Rove Estuary-the Kara Sea. Oceanology 2010, 50, 771-784. [CrossRef]

59. Martin, J.H.; Knauer, G.A. The elemental composition of plankton. Geochim. Cosmochim. Acta 1973, 37, 1639-1653. [CrossRef]

60. Demina, L.L. On the concentration function of bottom fauna deep-sea in hydrothermal vent areas. Doklady Earth. Sci. 2010, 430, 114-118. [CrossRef] 